\title{
Preclinical Lead Optimization of a 1,2,4-Triazole Based Tankyrase Inhibitor
}

Jo Waaler, ${ }^{*, \#}$ Ruben G. G. Leenders, "Sven T. Sowa," Shoshy Alam Brinch, Max Lycke, Piotr Nieczypor, Sjoerd Aertssen, Sudarshan Murthy, Albert Galera-Prat, Eddy Damen, Anita Wegert, Marc Nazaré, Lari Lehtiö, and Stefan Krauss

Cite This: J. Med. Chem. 2020, 63, 6834-6846

Read Online

ACCESS | Llll Metrics \& More | 回 Article Recommendations | St Supporting Information
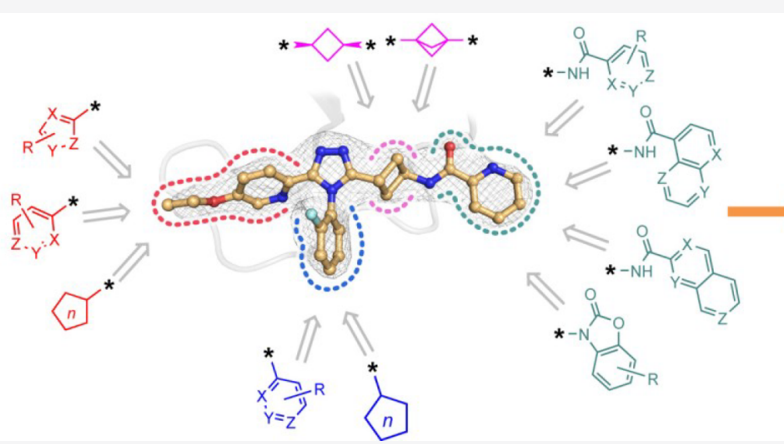

- TNKS1 IC $\mathrm{I}_{50}: 127 \mathrm{nM}$

- TNKS2 IC ${ }_{50}: 14 \mathrm{nM}$

- WNT/ $\beta$-catenin signaling $I C_{50}: 19 \mathrm{nM}$

- Selective (no PARP inhibition)

- Eliminated atropisomerism and solubility liabilities

- Favorable ADME and off-target safety profile

- >15-fold increased exposure (mouse PK)

- Anti-proliferative efficacy in colorectal cancer cell line

ABSTRACT: Tankyrases 1 and 2 are central biotargets in the WNT/ $\beta$-catenin signaling and Hippo signaling pathways. We have previously developed tankyrase inhibitors bearing a 1,2,4-triazole moiety and binding predominantly to the adenosine binding site of the tankyrase catalytic domain. Here we describe a systematic structure-guided lead optimization approach of these tankyrase inhibitors. The central 1,2,4-triazole template and trans-cyclobutyl linker of the lead compound 1 were left unchanged, while sidegroup East, West, and South moieties were altered by introducing different building blocks defined as point mutations. The systematic study provided a novel series of compounds reaching picomolar $\mathrm{IC}_{50}$ inhibition in $\mathrm{WNT} / \beta$-catenin signaling cellular reporter assay. The novel optimized lead 13 resolves previous atropisomerism, solubility, and Caco-2 efflux liabilities. 13 shows a favorable ADME profile, including improved Caco-2 permeability and oral bioavailability in mice, and exhibits antiproliferative efficacy in the colon cancer cell line COLO 320DM in vitro.

\section{INTRODUCTION}

Tankyrase 1 and tankyrase 2 (TNKS1/2) are members of the PARP family of enzymes that control protein activities, interactions, and turnover through mono- or poly-ADPribosylation. ${ }^{1}$ TNKS1/2 regulate a number of target proteins, including AXIN1 and AXIN2 (AXIN1/2) in the $\beta$-catenin destruction complex resulting in $\mathrm{WNT} / \beta$-catenin signaling pathway inhibition, and AMOT proteins in the Hippo signaling pathway resulting in YAP signaling inhibition. ${ }^{1-3}$ Tankyrases, through their ankyrin repeat clusters, bind to AXIN1/2, making AXIN1/2 accessible for ADP-ribosylation by the C-terminal TNKS $1 / 2$ catalytic domain. ${ }^{1} \mathrm{AXIN} 1 / 2$ is subsequently targeted for proteasomal degradation through polyubiquitination of E3 ubiquitin ligase RNF146, recognizing the poly-ADP-ribose signal. ${ }^{1,2}$ Destabilization of AXIN1/2, being a structural protein in the $\beta$-catenin destruction complex, leads to increased $\beta$-catenin levels which can be counteracted by inhibition of TNKS1/2 catalytic activity. ${ }^{1,2}$ Similarly, TNKS1/2 control the stability of AMOT proteins via RNF146. Stabilization of AMOT proteins by inhibiting
TNKS1/2 activity sequesters YAP to the cytoplasm and prevents target gene expression driven by YAP in the nucleus. ${ }^{1,3}$ TNKS1/2 catalytic activities also interfere with other biological mechanisms and cell signaling pathways such as vesicle transport, energy metabolism, telomere homeostasis, and mitotic spindle formation and affect components in AKT/ PI3K and AMPK signaling pathways. ${ }^{1,4-6}$

Several groups of chemical substances have been identified that inhibit TNKS1/2 by binding to the substrate $\mathrm{NAD}^{+}$ binding site either by occupying a nicotinamide pocket, adenosine binding pocket or by addressing both of them. $2,7-20$ Although the catalytic domains of 17 human ARTD/PARP enzymes are homologous, unique features in the TNKS1/2

Received: February 5, 2020

Published: June 8, 2020 
catalytic domain allow the development of tankyrase-selective chemical inhibitors. ${ }^{1}$ Despite this progress, there is currently no viable selective TNKS1/2 inhibitor in clinical testing or practice for any application including targeting the $\mathrm{WNT} / \beta$ catenin and YAP signaling pathways in cancer therapy. ${ }^{17,21-23}$

It has been shown that TNKS1/2 inhibitors can exhibit anticancer efficacy in mouse models, either as monotherapy against colorectal cancer ${ }^{8,24}$ and osteosarcoma ${ }^{25}$ or in combination therapies together with PI3K and EGFR inhibitors against colorectal cancer ${ }^{26}$ or with PD-1 inhibition against melanoma. ${ }^{27}$

Two reports indicate intestinal toxicity ${ }^{24}$ and bone loss $^{28}$ in mouse models upon treatment with early lead-stage tankyrase inhibitors, while other reports do not document signs of toxicity, intestinal injury, or body weight changes. ${ }^{8,26,27,29}$ Hence, there is a continued need for the development of safe drugs directed toward TNKS1/2 and the WNT/ $\beta$-catenin signaling pathway with improved chemical and biophysical properties. ${ }^{17,21-23}$

The compound optimization described here is based on the understanding of the structure-activity relationship, crystallography, and physicochemical properties of our previous 1,2,4triazole analogue series JW74, ${ }^{30}$ G007-LK, ${ }^{9}$ and OD336 (1). ${ }^{11}$ The optimization focused especially on the solubility and atropisomerism liabilities of the former G007-LK and 1 compounds, respectively. In our work we developed a novel series of compounds reaching picomolar $\mathrm{IC}_{50}$ activity in a cellular $\mathrm{WNT} / \beta$-catenin signaling reporter assay. Lead compound OM-1700 (13) within the novel series displays high potency and specificity and has overall favorable ADME properties compared to benchmark tankyrase inhibitors.

\section{RESULTS AND DISCUSSION}

Chemistry. For the synthesis of novel structures in the optimization campaign, we embraced a building block approach (Figure 1). Herein we were able to prepare all compounds following the same synthetic route, simplifying synthesis efforts (Scheme 1). Cyclic amide/urea/carbamate East modifications, however, required a different route (Scheme 2). Since the 1,2,4-triazole as a central scaffold was well established in our previous research, ${ }^{9}$ it was left unchanged in the present lead optimization process. In the linker area between the 1,2,4-triazole and the East moieties, we synthesized a series of analogues with a bicyclo[1.1.1]pentane configuration and one compound with a cis-cyclobutane setup. These linker variations were synthesized according to the same scheme as for the default trans linker. For further optimization, the trans-cyclobutyl linker was left unchanged for the majority of the target molecules as it proved to be superior to the tested alternative linker iterations. ${ }^{11}$

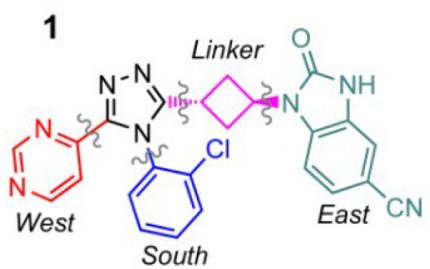

Figure 1. Lead compound $\mathbf{1}$ and the building blocks defined as West (red), South (blue), East (green), and linker (pink).
For compounds having the benzimidazolone West moiety of 1, synthesis was performed as depicted in Scheme 1a and described in our previous work. ${ }^{11}$ For East-side variations, a slightly different route enabling East variations in the last step departing from amine $\mathbf{G}$ was used (Scheme $1 \mathrm{~b}$ ).

As a first iteration, we replaced the East benzimidazolone group as in our experience this group can result in unwanted solubility, permeability, and efflux properties. When suitable East-amides were identified as a replacement for the benzimidazolone group, a wide range of further options for East-side iterations opened enabling fine-tuning of physicochemical properties. Next, we replaced the West-pyrimidine as this group renders the molecule vulnerable for CYP-mediated oxidation which was confirmed by Med-Id studies of $\mathbf{1}$.

To synthesize a broad set of targets, we optimized the triazole-forming reaction from $\mathbf{E}$ to $\mathbf{G}$ (Scheme $1 \mathrm{~b}$ ) from the existing method (TFA, DMA, $120{ }^{\circ} \mathrm{C}, 14 \mathrm{~h}, 10-21 \%$ yield). Here, we found that heating of $\mathbf{E}$ and $3 \mathrm{a}$ in 1-butanol at 80$140{ }^{\circ} \mathrm{C}$ for $5-20 \mathrm{~h}$, depending on the actual substrate, typically resulted in $60-90 \%$ yield. Under these conditions, a broader scope of South and West moieties was tolerated in the reaction. All compounds in the present study were prepared accordingly except the benzisoxazolone 18 and lactam 51 (Scheme 2). For compounds with the cis-cyclobutane (75) and bicyclo[1.1.1]pentane (19) moieties, the corresponding hydrazides $3 b$ and $3 c$ respectively were used (Scheme $1 b$ ).

Biological Evaluation. All compounds were tested using a TNKS2 biochemical assay and a luciferase-based WNT/ $\beta$ catenin signaling pathway reporter assay in human HEK293 cells. ${ }^{9}$ In the first round of the optimization campaign, we prepared single-point modifications changing any of the four regions in 1 (Figure 1) while leaving the other regions constant. In the following stages of the optimization campaign, additional East, West, and South moieties were also utilized, combining the best structural elements of the first single-point modification round. For the optimization, in vitro ADME properties and solubility of selected compounds were measured. Mouse pharmacokinetics, after oral dosing, was tested for the selected and short-listed compounds 13, 16, and 27 (Figure 2c and indicated by \# in Tables 1 and 2).

Since 1 displayed low solubility and high Caco- 2 efflux, ${ }^{11}$ we substituted the benzimidazolone $\mathrm{NH}$ group by forming the $\mathrm{N}$ Me variant $17 ;^{31}$ however, this resulted in a 20 -fold less efficacious compound (Figure 2a). Likewise, the oxygencontaining analogue 18 displayed decreased efficacy when compared to $\mathbf{1}$ (Figure $2 \mathrm{a}$ ). We then replaced the benzimidazolone moiety, ${ }^{10,20}$ as this can inflict high efflux and low solubility by a series of East-positioned amides. From these amides, 20 and $\mathbf{2 1}$ turned out to be the most potent resulting in picomolar cellular inhibitory $\mathrm{IC}_{50}$ efficacies (Figure 2a). Solubility and Caco-2 cell permeation were completely restored in $\mathbf{2 1}$ (Figure $2 \mathrm{~b}$ ). The amide having the $\mathrm{N}$-Me group (44) was inactive, whereas activity was restored in the cyclic version (51) (Supplementary Table 1a). Nonaromatic amides $(52,53$, and 54) resulted in inactive compounds (Supplementary Table 1a).

To interrogate the West-side of the pharmacophore, pyridine and pyrimidine analogues were prepared. These compounds inhibited the cellular $\mathrm{WNT} / \beta$-catenin signaling pathway reporter assay to a similar extent as lead 1 , except the 2-pyrimidyl substituted compound (56). The ethoxypyridyl derivative $\mathbf{2 2}$ was consequently selected as a starting point for further hybrid synthesis (Figure 2a and Supplementary Table 
Scheme 1. (a, Left) Synthesis of Targets with South and West Variations and (b, Right) Synthesis of Targets with East Variations
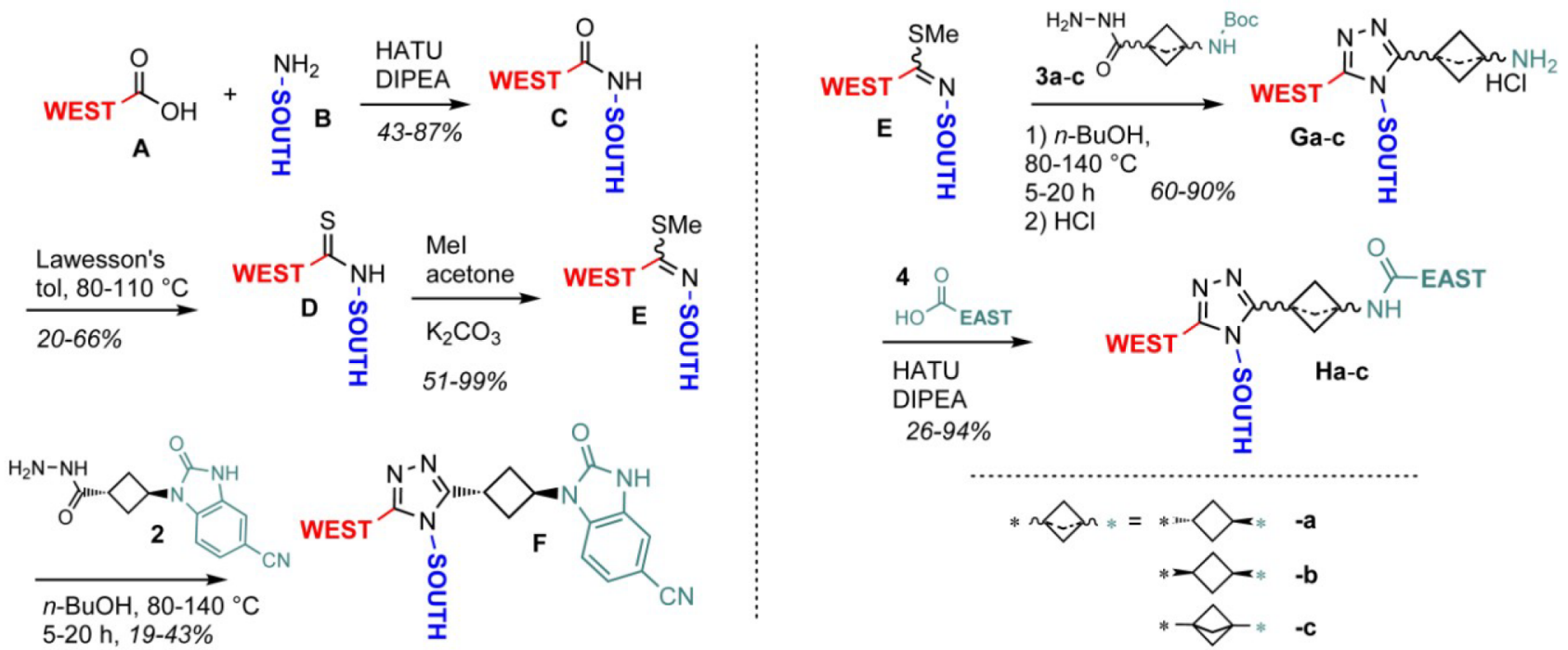

2) $\mathrm{HCl}$

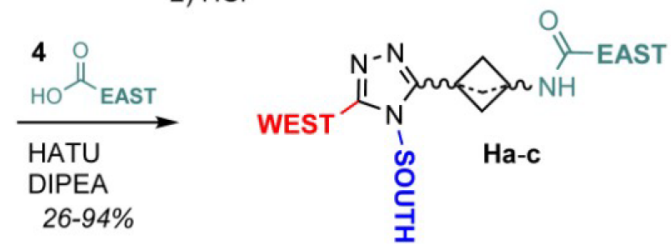

Scheme 2. Synthesis of 18 and 51
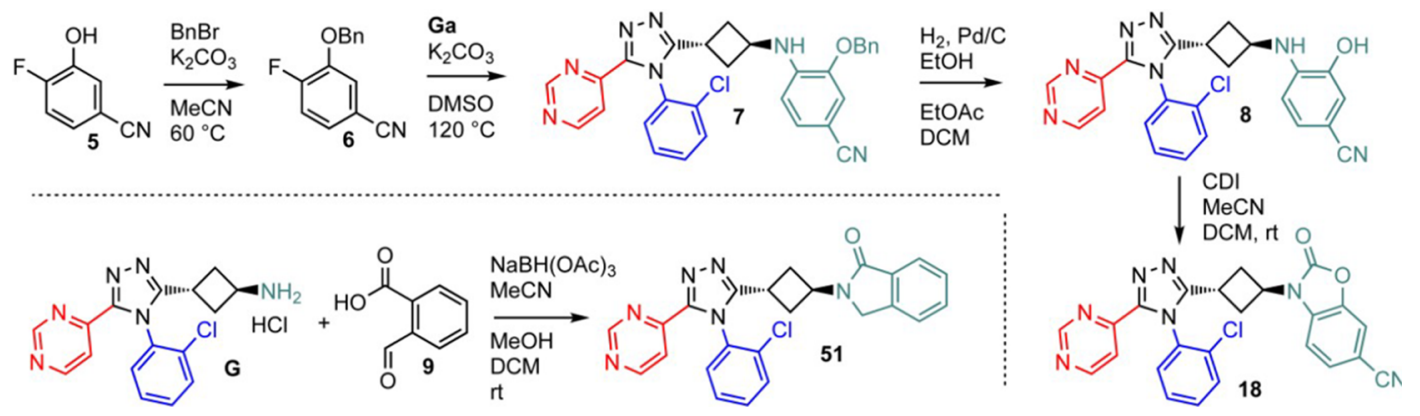

1b). Introduction of thiazoles to replace the six-membered heterocycle resulted in less efficacious compounds, with $\mathbf{5 9}$ displaying the most favorable properties in this cluster (Supplementary Table 1b). Introduction of aliphatic rings, such as cyclopentane in 63 and cyclopropane in $\mathbf{6 4}$, indicated that aromatic ring systems are required in this position for maintaining potency (Supplementary Table $1 b$ ).

Next, in a series of synthesized South-aryl products, the 2trifluoromethyl (66) showed comparable activities to the previous lead 1 (Supplementary Table 1b). The thiophenyl moeity as a bioisosteric replacement for the aryl group was less tolerated, while cycloalkyl replacements resulted in activities in the micromolar range (Supplementary Table 1c).

Linker variations were addressed with the cis-cyclobutyl linker and bicyclo[1.1.1]pentane linker 75 and 19, respectively (Supplementary Table 1d). Compound 75 displayed decreased potency (Supplementary Table 1d), while compound 19 suffered from low solubility (Figure $2 b$ ). Despite the more rigid geometry of the bicyclo[1.1.1] pentane in comparison to trans-cyclobutyl of 1 , the cocrystal structure with TNKS2 showed a very similar binding mode at the $\mathrm{NAD}^{+}$binding cleft (Figure 3). 105 occupied the adenosine subpocket and formed the typical hydrogen bonds to the backbone amides of Tyr1060 and Asp1045 (Figure 3a and Supplementary Figure 1a). A water molecule forms bridging interactions between the pyridine nitrogen and Gly1058 and Tyr1050, and the same applies to all the cocrystal structures described (Figure 3a).
Rotational isomerism (atropisomerism) is a known phenomenon for substituted triazoles and can potentially lead to complexity and challenges for the drug discovery and development processes as atropisomers might have differing biological activities toward a target, different off-target profiles, and different pharmacokinetic properties. ${ }^{32,33}$ Since $\mathbf{1}$ does not contain asymmetric centers, atropisomers are mirror images (enantiomers). Hence, on an achiral HPLC column, as well as in NMR, such atropisomers are indiscernible. In contrast, on a chiral SFC column, lead 1 showed two signals indicating rotational isomerism (Figure 4). When separated, these isomers did not interconvert at $20{ }^{\circ} \mathrm{C}$ for $72 \mathrm{~h}$ but showed a minor interconversion at $70{ }^{\circ} \mathrm{C}$ during $72 \mathrm{~h}$ (Figure 4). Interestingly, both isomers, 1-AT-1 and 1-AT-2, differed in potency and efficacy with a factor of 30 to almost 60, respectively (Figure 4). To investigate whether atropisomerism was induced by the South 2-chlorophenyl substituent, we analyzed all synthesized compounds with chiral SFC. All compounds with a South 2-chlorophenyl group showed atropisomers, while compounds without this group, including the symmetric 2,6-dichlorophenyl 67, did not (Supplementary Table 1c). In addition, 66, containing a bulky 2 -trifluoromethyl group, also showed two signals on a chiral SFC column. No rotamers were observed for the 2-fluorophenyl South group at room temperature. Hence, this group was considered a viable substitution to avoid atropisomerism. As a consequence, in the following optimization campaign, the South 2-chlorophenyl 
a)

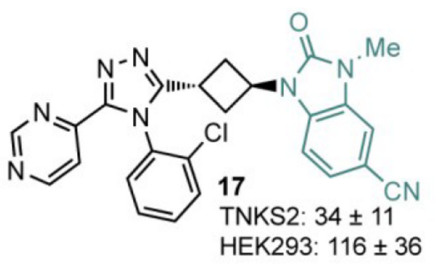

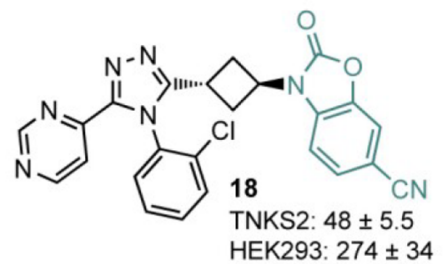<smiles>[Y10][R16]#N</smiles><smiles>[AlH2]</smiles>
HEK293: $274 \pm 34$ HEK293: $4.7 \pm 1.1$

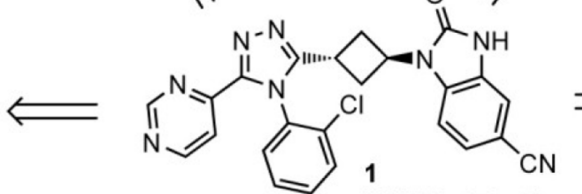

TNKS2: $6.3 \mathrm{nM}$ HEK293: $19 \mathrm{nM}$

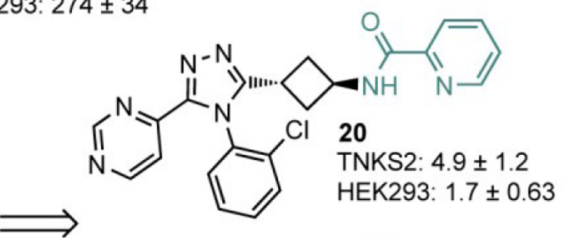

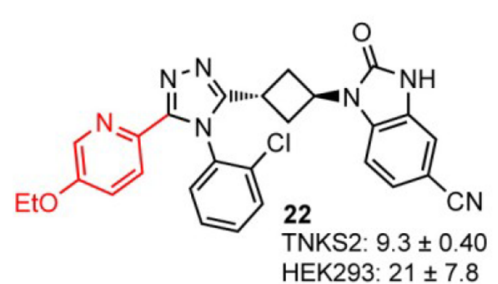<smiles>C=C</smiles>

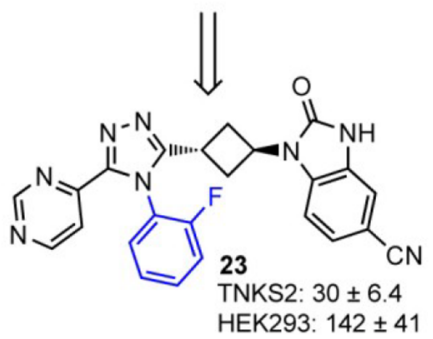<smiles>O=C(N[C@H]1C[C@H](c2nnc(-c3ccncn3)n2-c2ccccc2Cl)[C@@H]1Cl)c1ccnc2cccnc12</smiles>

Key compounds Shortlisted compounds

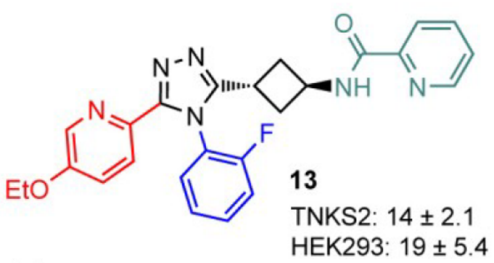

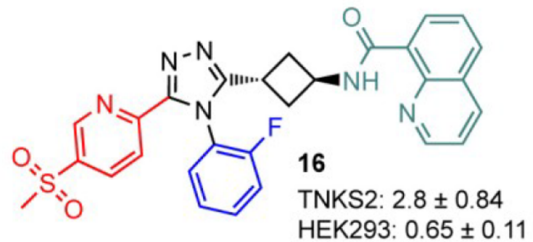

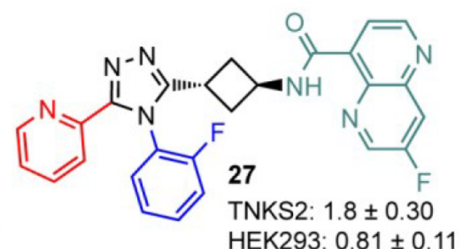

b)

\begin{tabular}{c|c|c|c|c} 
ID & $\begin{array}{c}\text { Kinetic Solubility } \\
\mathrm{pH} 7.4(\mu \mathrm{M})\end{array}$ & $\begin{array}{c}\text { Caco-2 permeability } \\
\mathrm{Papp}_{\text {ap }} \mathbf{A B} \\
\left(10^{-6} \mathrm{~cm} / \mathrm{s}\right) / \text { efflux ratio }\end{array}$ & \multicolumn{2}{|c}{$\begin{array}{c}\text { Microsomal stability } \\
\mathrm{CL}_{\text {int }}(\mu \mathrm{L} / \mathrm{min} / \mathrm{mg} \text { protein }) / \mathbf{t}_{1 / 2}(\mathrm{~min})\end{array}$} \\
human & mouse \\
\hline $\mathbf{1}$ & 12 & $10 / 4.2$ & $242 / 6$ & $204 / 7$ \\
\hline $\mathbf{1 9}$ & 1.5 & $5.0 / 5.3$ & $200 / 7$ & $256 / 5$ \\
\hline $\mathbf{2 0}$ & $>80$ & & $<15 />90$ & $125 / 11$ \\
\hline $\mathbf{2 1}$ & 79 & $31 / 1.2$ & $227 / 6$ & $411 / 3$ \\
\hline $\mathbf{2 2}$ & & & $<15 />90$ & $57 / 24$
\end{tabular}

C)

\begin{tabular}{c|c|c|c|c|c|c|c|c|c} 
ID & $\begin{array}{c}\text { HEK293 IC50 } \\
(\mathrm{nM} \pm \mathrm{SD})\end{array}$ & $\begin{array}{c}\mathrm{T}_{1 / 2} \\
(\mathrm{~h})\end{array}$ & $\begin{array}{c}\mathrm{T}_{\max } \\
(\mathrm{h})\end{array}$ & $\begin{array}{c}\mathrm{C}_{\max } \\
(\mathrm{ng} / \mathrm{mL})\end{array}$ & $\begin{array}{c}\mathbf{A U C ~ 0 \rightarrow t} \\
\left(\mathrm{ng} / \mathrm{mL} \mathbf{*}^{*}\right)\end{array}$ & $\begin{array}{c}\text { AUC 0 } \rightarrow \infty \\
\left(\mathrm{ng} / \mathrm{mL} \mathbf{n}^{*}\right)\end{array}$ & $\begin{array}{c}\text { MRT 0 } \rightarrow \infty \\
(\mathrm{h})\end{array}$ & $\begin{array}{c}\mathbf{V d} \\
(\mathrm{L} / \mathrm{Kg})\end{array}$ & $\begin{array}{c}\mathrm{CL} \\
(\mathrm{L} / \mathrm{h} / \mathrm{Kg})\end{array}$ \\
\hline $\mathbf{1}$ & 19 & 1.51 & 0.25 & 124 & 145 & 147 & 1.61 & 74.2 & 34.0 \\
\hline $\mathbf{1 3}$ & $19 \pm 5.4$ & 0.67 & 0.25 & 3203 & 2384 & 2388 & 0.69 & 2.03 & 2.09 \\
\hline $\mathbf{1 6}$ & $0.65 \pm 0.11$ & 0.76 & 0.5 & 1448 & 2955 & 2963 & 1.73 & 1.86 & 1.69 \\
\hline $\mathbf{2 7}$ & $0.81 \pm 0.11$ & 0.95 & 0.25 & 3419 & 5033 & 5057 & 1.43 & 1.35 & 0.99
\end{tabular}

Figure 2. (a) Selected key compounds in the optimization campaign and respective TNKS2 and HEK293 IC 50 values. Mean \pm SD values for three independent experiments are shown. Moieties are in color when differing from 1. (b) ADME data of key compounds. (c) Cellular efficacy and mouse po PK $5 \mathrm{mg} / \mathrm{kg}$ of the short-listed compounds. 
Table 1. Hybrids Derived from 19 and 20, 22, and three West Moieties ${ }^{a}$

\begin{tabular}{|c|c|c|c|c|c|c|c|}
\hline ID & Hybrids & $\begin{array}{c}\text { TNKS2 } \\
\text { IC }_{50} \\
(\mathrm{nM})\end{array}$ & $\begin{array}{c}\text { HEK293 } \\
\text { IC }_{50} \\
(\mathrm{nM})\end{array}$ & $\begin{array}{c}\text { Kinetic } \\
\text { Solubility } \\
\text { pH } 7.4 \\
(\mu \mathrm{M})\end{array}$ & $\begin{array}{c}\text { Caco-2 } \\
\text { permeability } \\
P_{\text {app }} A B \\
\left(10^{-6} \mathrm{~cm} / \mathrm{s}\right) / \\
\text { efflux ratio }\end{array}$ & $\begin{array}{c}\text { Microso } \\
(\mu \mathrm{L} / \mathrm{min} / \mathrm{mg} \\
\text { human }\end{array}$ & $\begin{array}{l}\text { stability } \\
\text { t.) } / \mathrm{t}_{1 / 2}(\min ) \\
\text { mouse }\end{array}$ \\
\hline 10 & & 4.3 & 0.63 & $>80$ & $34 / 0.6$ & $24 / 58$ & $203 / 8$ \\
\hline 11 & & 3.3 & 3.9 & 2.9 & $34 / 0.8$ & & \\
\hline 12 & & 1.1 & 0.42 & & $3.8 / 18$ & $36 / 39$ & $41 / 33$ \\
\hline $\begin{array}{c}13 \\
\#\end{array}$ & & 14 & 19 & $>80$ & $40 / 0.6$ & $<15 />90$ & $37 / 36$ \\
\hline 14 & & 29 & 127 & & & & \\
\hline 15 & & 9.2 & 12 & & & $<15 />90$ & $<15 />90$ \\
\hline $\begin{array}{c}16 \\
\#\end{array}$ & & 1.8 & 0.81 & $>36$ & $14 / 2.9$ & $<15 />90$ & $37 / 37$ \\
\hline
\end{tabular}

$a_{\#}$ indicates that these compounds were evaluated in a mouse pharmacokinetics analysis.

Table 2. 2D East (Green) and West Library (Red) with TNKS2 IC $_{50}(\mathrm{nM})$, HEK293 IC $_{50}(\mathrm{nM})$, and Solubility $(\boldsymbol{\mu M})$ Values Depicted ${ }^{a}$

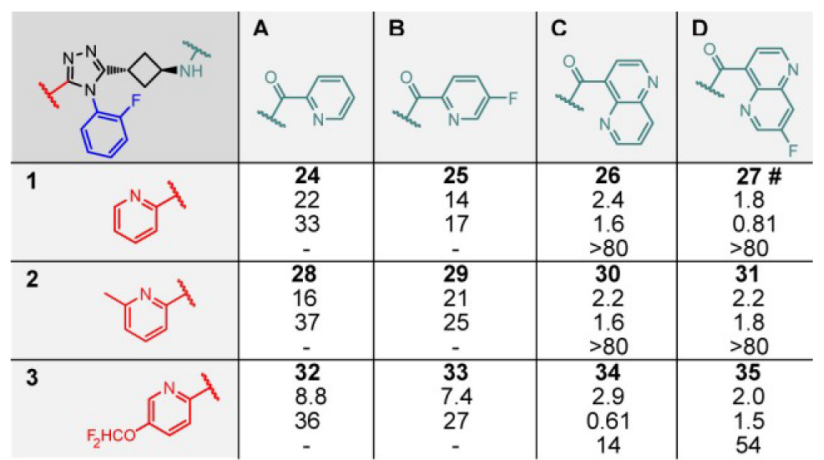

$a_{\#}$ indicates that the compound was evaluated in a mouse pharmacokinetics analysis.

moiety was replaced with the 2-fluorophenyl group of $\mathbf{2 3}$ resulting in acceptable efficacy compared to other substitutions (Figure 2a and Supplementary Table 1c).
The comparison of the binding modes of the 2-halogensubstituted compounds showed that the chlorine or fluorine atoms were pointing into the same direction in the TNKS2 active site (Figure 3 and Supplementary Figure $1 \mathrm{~b}-\mathrm{e}$ ). This is in agreement with the clear difference in the measured potencies of the atropisomers (Figure 4). The South moiety without a halogen was less potent, had similar orientation in the binding pocket, but caused a conformational change in the Tyr1050 covering the active site (Supplementary Figure 1d).

Next, all possible hybrid combinations were synthesized employing the East moieties of compounds 20 and 21, a South 2-fluorophenyl group, and three different West moieties revisiting the 2-pyridyl-4-methylsulfonyl moiety as well (Table 1). ${ }^{9}$ From these six molecules, compounds with the 1,5-naphthyridine moiety $(\mathbf{1 0}, \mathbf{1 1}$, and 12) showed approximately 30 -fold improved cellular inhibitory efficacy compared to their counterparts with the 2-pyridyl moiety $(13,14$, and 15 , respectively, Table 1). The binding mode of compound 13 in cocrystal structures was similar, and the hydrogen bonds to the backbone amides seen in the $\mathbf{1}$ cocrystal structures were retained (Figure 3 and Supplementary Figure $1 \mathrm{~b}$ ). The large East moieties 1,5- and 1,6-naphthyridine (e.g., see 87, 88, 106, and 107 Supplementary Figure 4a) appeared to form a more 

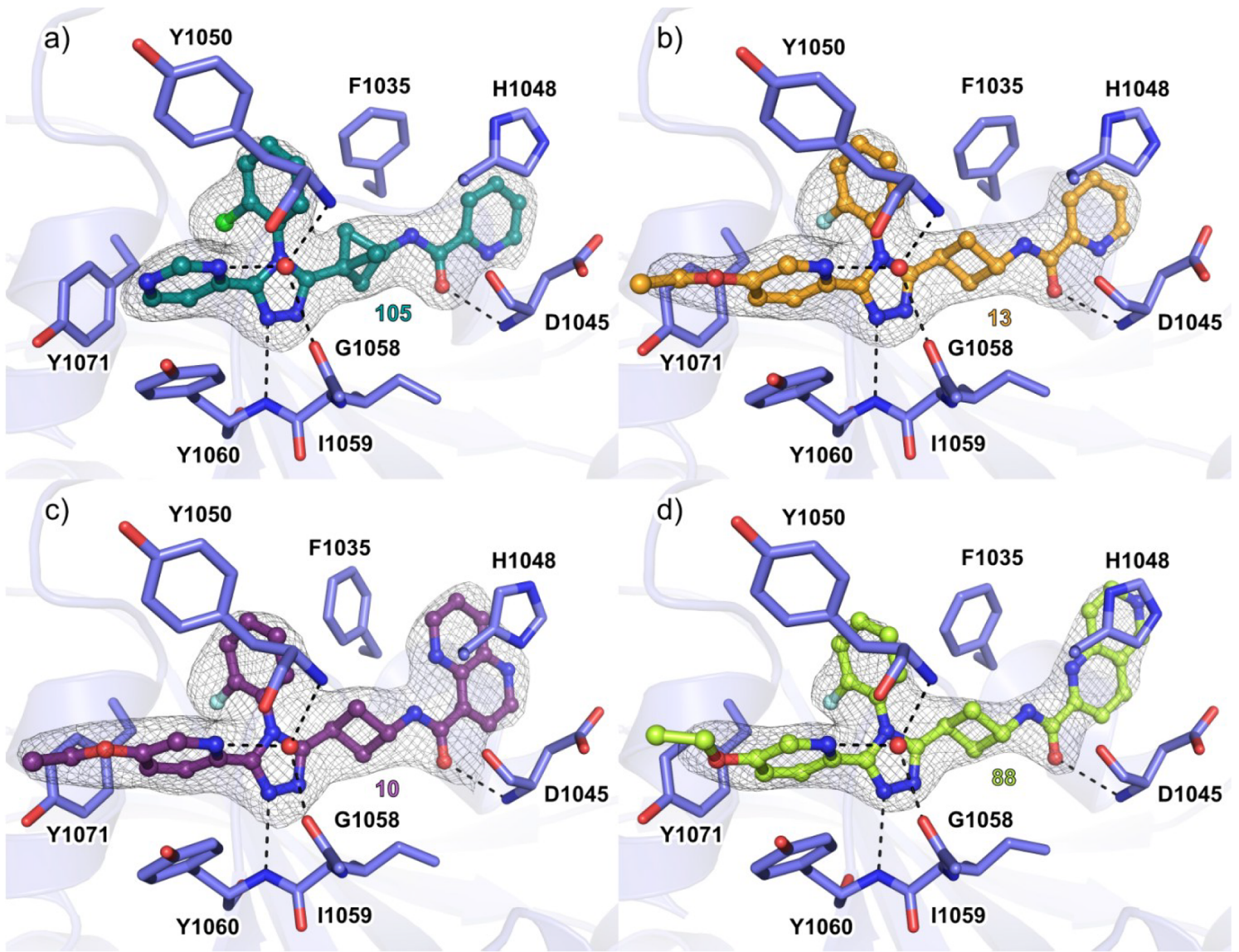

Figure 3. Cocrystal structures of TNKS2 with inhibitors. (a) Binding mode of 105 with TNKS2 catalytic domain (PDB code 6TKN). (b) Binding mode of 13 with TNKS2 catalytic domain (PDB code 6TG4). (c) Binding mode of 10 with TNKS2 catalytic domain (PDB code 6TKM). (d) Binding mode of $\mathbf{8 8}$ with TNKS2 catalytic domain (PDB code 6TKS). The dashed lines in black represent hydrogen bonds, and the red spheres represent water molecules. The $\sigma_{\mathrm{A}}$ weighted $2 F_{\mathrm{o}}-F_{\mathrm{c}}$ electron density maps around the ligands are contoured at $(1.4-1.7) \sigma$. Structures were solved with molecular replacement using the structure of TNKS2 (PDB code 5NOB) as a starting model.

PDA - total absorbance chromatogram

$72 \mathrm{~h}, 20^{\circ} \mathrm{C}$

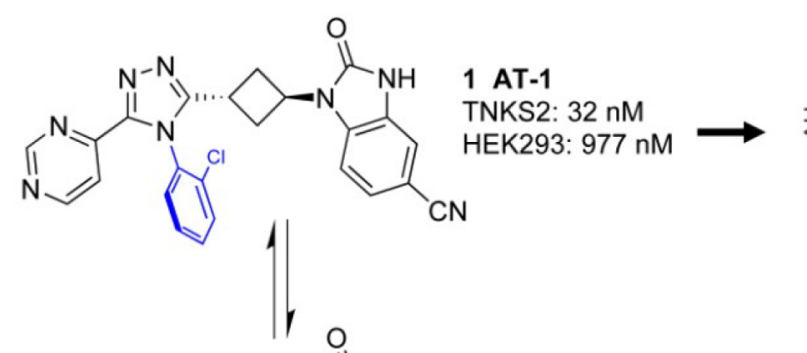<smiles>O=c1[nH]c2cc(Cl)ccc2n1C1CC(c2nnc(-c3ccncn3)n2-c2ccccc2)C1</smiles>

1 AT-2

TNKS2: $1.1 \mathrm{nM}$ HEK293: $17 \mathrm{nM}$

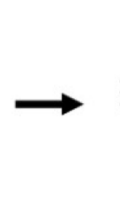

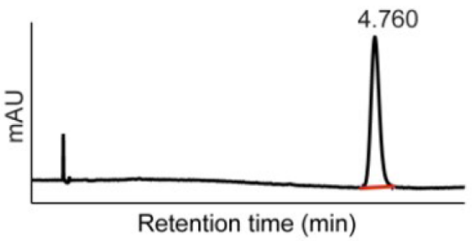

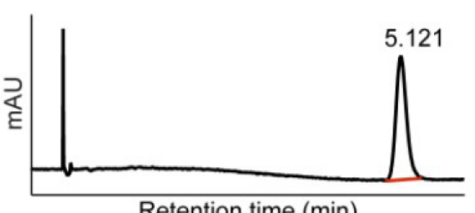

$72 \mathrm{~h}, 70^{\circ} \mathrm{C}$
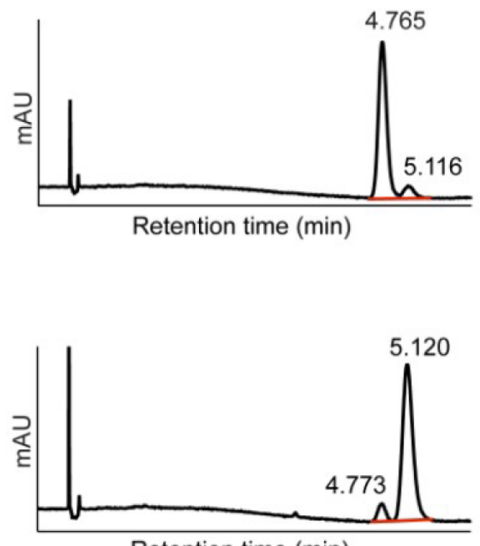

Retention time $(\mathrm{min})$

Figure 4. Atropisomerism of $\mathbf{1}$ (stereochemistry arbitrarily assigned) on chiral SFC and TNKS2 and HEK293 IC $_{50}$ values.

efficient $\pi-\pi$-stacking interaction with His1048 and a hydrophobic interaction with Phe1035, causing the side chain to gradually rotate according to the form of the East moiety (Figure 3c,d, Supplementary Figure 1c-e, Supplementary Table 2). However, compounds with this naphthyridine moiety were less stable in microsomes relative to the corresponding East-pyridines, and consequently, 13 was shortlisted for mouse pharmacokinetics studies. In addition, the quinoline-containing 16 displayed similar inhibition in the cellular WNT reporter assay compared to 12 and also possessed improved calculated physical-chemical properties (ChemAxon, $\operatorname{cLog} \mathrm{P}=3.0 / 3.7, \mathrm{tPSA}=128 / 141$ for 16 and 12, 
Table 3. Profiling of 1 and $13^{a}$

\begin{tabular}{|c|c|c|}
\hline parameter & 1 & 13 \\
\hline MW (g/mol) & 468.91 & 458.50 \\
\hline ALogP (LiveDesign 8.6) & 4.7 & 3.6 \\
\hline AlogD (LiveDesign 8.6) & 5.3 & 4.0 \\
\hline tPSA (LiveDesign 8.6) $\left(\AA^{2}\right)$ & 118.1 & 94.8 \\
\hline TNKS1 $\left(\mathrm{IC}_{50}, \mathrm{nM}\right)$ & 29 & 127 \\
\hline TNKS2 $\left(\mathrm{IC}_{50}, \mathrm{nM}\right)$ & 6.3 & 14 \\
\hline PARPs/ARTDs $\left(\mathrm{IC}_{50}, \mu \mathrm{M}\right)$, ARTD $1 / 2 / 3 / 4 / 7 / 8 / 10 / 12$ & $>10$ & $>10$ \\
\hline HEK293 cells $\left(\mathrm{IC}_{50}, \mathrm{nM}\right)$ & 19 & 19 \\
\hline kinetic solubility, $\mathrm{PBS}, \mathrm{pH}=7(\mu \mathrm{M})$ & 12 & 95.7 \\
\hline Caco-2 A-B: $P_{\text {app }}\left(10^{-6} \mathrm{~cm} / \mathrm{s}\right)$ & 10.0 & 39.5 \\
\hline Caco-2 efflux ratio & 4.17 & 0.610 \\
\hline microsomal stability, human/mouse, $\mathrm{Cl}_{\mathrm{mt}}((\mu \mathrm{L} / \mathrm{min}) / \mathrm{mg}$ protein $)$ & $242 / 204$ & $<15 / 37$ \\
\hline hepatocyte stability, human/mouse/dog/rat/cynomolgus, $\mathrm{Cl}_{\text {int }}\left((\mu \mathrm{L} / \mathrm{min}) / 10^{6}\right.$ cells $)$ & $9.8 / \mathrm{ND} / \mathrm{ND} / \mathrm{ND} / \mathrm{ND}$ & $<0.1 / 28 /<0.1 / 3.8 /<0.1$ \\
\hline CYP3A4 inhibition $\left(\mathrm{IC}_{50}, \mu \mathrm{M}\right)$ & 1.26 & $>25$ \\
\hline mouse plasma stability $t_{1 / 2}(\mathrm{~min})$ & & 880 \\
\hline mouse PPB (\%) & & 93.92 \\
\hline hERG inhibition $\left(\mathrm{IC}_{50}, \mu \mathrm{M}\right)$ & & $>25$ \\
\hline Ames test & & nongenotoxic \\
\hline Cerep safety panel, 44 targets $(10 \mu \mathrm{M})$ & & clean (A2A, 53\% inhib) \\
\hline bioavailability $F(\%)$ & 47 & 107 \\
\hline po PK mouse $t_{1 / 2}(\mathrm{~h})$ & 1.5 & 0.67 \\
\hline po $\mathrm{PK}$ mouse $\mathrm{Cl}((\mathrm{L} / \mathrm{h}) / \mathrm{kg})$ & 34.0 & 2.09 \\
\hline po PK mouse Vd (L/kg) & 74.2 & 2.03 \\
\hline po PK mouse $\mathrm{AUC}_{0 \rightarrow t}$ & 145 & 2384 \\
\hline
\end{tabular}

${ }^{a} \mathrm{ND}=$ not determined.

a)

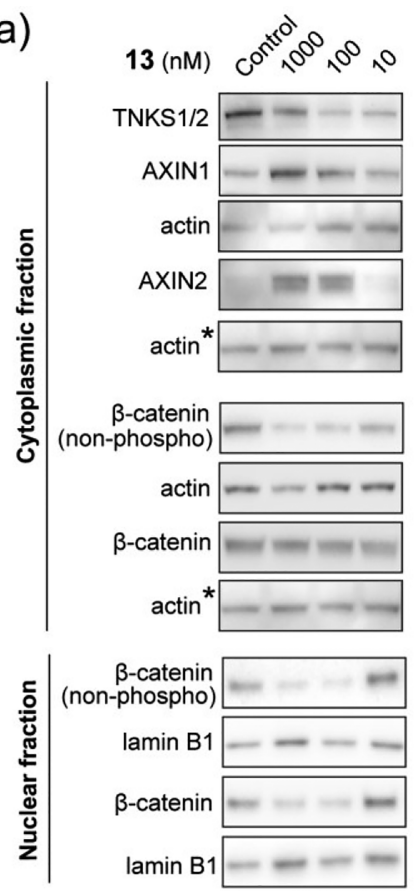

b)
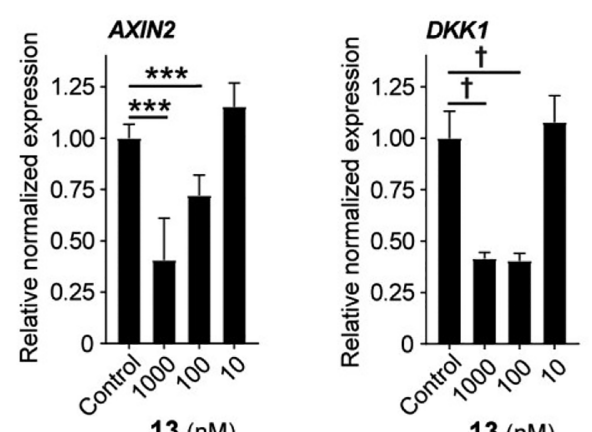

$13(\mathrm{nM})$
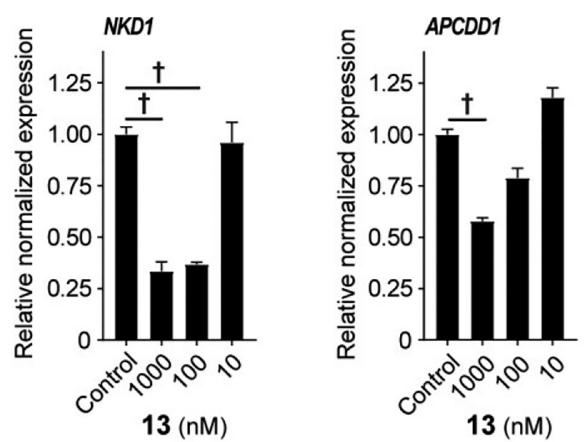

c)

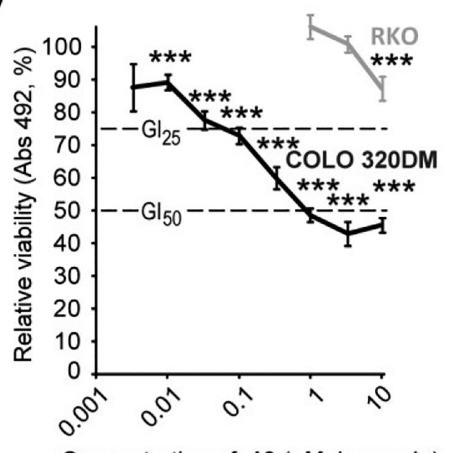

Concentration of $13(\mu \mathrm{M}$, log scale)

Figure 5. 13 can inhibit WNT/ $\beta$-catenin signaling activity and act as an antiproliferative agent in COLO 320DM cells. (a) Representative immunoblots of cytoplasmic TNKS1/2, AXIN1, AXIN2 and cytoplasmic and nuclear transcriptionally active $\beta$-catenin (non-phospho) and $\beta$ catenin. Actin or lamin B1 document equals protein loading, and $*$ indicates that the same actin immunoblot is used as loading control for both AXIN2 and $\beta$-catenin. For (a) and (b), control $=0.01 \%$ DMSO. (b) Real-time RT-qPCR analyses of WNT $/ \beta$-catenin signaling target genes $(A X I N 2, D K K 1, N K D 1$, and APCDD1). For $(\mathrm{b})$ and $(\mathrm{c})$, ANOVA tests (Holm-Sidak method, versus control) are indicated by $* * *(P<0.001)$, and ANOVA on ranks tests (Tukeys test versus control) are indicated by $\dagger(P<0.05)$. Mean values \pm standard deviations for combined data from a minimum of three independent experiments with three replicates each are shown. (c) MTS colorimetric cell growth assay for various doses of 13 in $\mathrm{APC}^{\text {mutated }}$ COLO 320DM (black) and APC ${ }^{\text {wild-type }} \mathrm{RKO}$ (gray) cells. Control $=0.1 \%$ DMSO. Dotted lines depict $50 \%\left(\mathrm{GI}_{50}\right)$ and $25 \%\left(\mathrm{GI}_{25}\right)$ growth inhibition levels. Mean values \pm standard deviations for one representative experiment out of three independent experiments are shown. 
respectively) (Figure $2 \mathrm{a}$ and Table 1 ). On the basis of these results, 16 was short-listed for mouse pharmacokinetics analysis. Further optimization focused on pyridine-type Westside variations and discarded the West 2-thiazole (11) because of adverse solubility and low efficacy (14) (Table 1). In an East and West 2D library, fluorinated analogues of the 2pyridyl and the 1,5-naphthyridine were introduced (Table 2 and Supplementary Table 2). From these compounds, 27 was short-listed for mouse pharmacokinetics analysis.

Compared to the initial benchmark lead compound 1, the peroral mouse pharmacokinetics data of the selected and shortlisted compounds showed significantly improved profiles exhibiting lower clearance and volume of distribution and 15-35 times higher exposure (Figure 2c). In due course of the study, 13 had been further characterized including selectivity toward other members of the PARP family, structural analysis of its binding mode, kinetic solubility, Caco-2 permeability and efflux, CYP3A4 inhibition, mouse plasma stability, mouse plasma protein binding, hERG inhibition, Ames test, and offtarget safety panel, exhibiting overall favorable parameters (Figure 3, Table 3, Supplementary Table 3 and Supplementary Figure 2).

Tankyrase inhibition can context-dependently antagonize proliferation and viability in cancer cell lines in vitro and in vivo, including in the colorectal adenocarcinoma cell line COLO 320DM harboring $\mathrm{WNT} / \beta$-catenin signaling-inducing $A P C$ mutations. ${ }^{5,22}$ Hence, cultured COLO $320 \mathrm{DM}$ cells were treated with various doses of $\mathbf{1 3}$ to evaluate the efficacy in reducing canonical $\mathrm{WNT} / \beta$-catenin signaling and the potential as an antiproliferative agent. As expected for a potent tankyrase inhibitor, treatment with 13 reduced TNKS1/2 protein levels, stabilized AXIN1 and AXIN2 proteins, and reduced the level of transcriptionally active $\beta$-catenin (nonphoshorylated) in both the cytoplasmic and nuclear fraction (Figure 5a and Supplementary Figure 3a,b). Administration of $\mathbf{1 3}$ also decreased transcription of the WNT $/ \beta$-catenin signaling target genes AXIN2, DKK1, NKD1, and APCDD1 (Figure 5b). Moreover, 13 exposure decreased proliferation and viability in COLO 320DM cells $\left(\mathrm{GI}_{50}=650 \mathrm{nM}\right.$ and $\left.\mathrm{GI}_{25}=94 \mathrm{nM}\right)$, while control $A P C^{\text {wild-type }}$ RKO colorectal cancer cells were only modestly affected by the treatment at a $10 \mu \mathrm{M}$ compound concentration (Figure 5c). In conclusion, these results authenticate that $\mathbf{1 3}$ can both potently and specifically inhibit $\mathrm{WNT} / \beta$-catenin signaling activity and act as an antiproliferative agent in COLO 320DM cells.

\section{CONCLUSION}

In summary, through a systematic building-block-based and crystallography-guided structure-activity-relationship analysis, we identified novel 1,2,4-triazole-based optimized lead tankyrase inhibitors with low nanomolar and picomolar $\mathrm{IC}_{50}$ activities in a $\mathrm{WNT} / \beta$-catenin signaling cellular reporter assay. The adverse chemical properties of the preceding lead compound $\mathbf{1}^{11}$ displaying atropisomerism and solubility liabilities, were excluded in the here identified advanced lead compound 13. Compound 13 shows high selectivity toward TNKS1/2, an overall favorable ADME, including highly improved Caco- 2 permeability and microsomal stability, a clean off-target safety profile, a $>15$-fold increased exposure in a mouse pharmacokinetics analysis, and a robust inhibition of $\mathrm{WNT} / \beta$-catenin signaling and proliferation in the colon cancer cell line COLO 320DM. Our work provides a considerably optimized compound for targeting TNKS1/2 and WNT/ $\beta$ catenin signaling in cancer and other disease models.

\section{EXPERIMENTAL SECTION}

General Methods. All starting materials and dry solvents were commercially obtained. The synthesis of hydrazide $\mathbf{2}$ was scaled up employing a similar procedure reported in our earlier publication. ${ }^{11}$ Reactions were performed under an inert atmosphere of nitrogen when necessary. Microwave reactions were carried out in sealed vials. Column chromatography was carried out on silica gel cartridges (40 $\mu \mathrm{m}$ irregular), and TLC analysis was performed on silica gel $60 \mathrm{~F}_{254}$ plates.

NMR. NMR spectra were recorded in chloroform- $d$, unless otherwise stated, on a $400 \mathrm{MHz}$ spectrometer with tetramethylsilane as internal standards. Coupling constants are given in $\mathrm{Hz}$. Peaks are reported as singlet $(\mathrm{s})$, doublet $(\mathrm{d})$, triplet $(\mathrm{t})$, quartet $(\mathrm{q})$, quintet $(\mathrm{p})$, sextet $(\mathrm{h})$, septet (hept), multiplet $(\mathrm{m})$, or a combination thereof. br stands for broad.

LC/MS. LC/MS chromatograms mass spectra were recorded using electrospray ionization in positive or negative ionization mode on Agilent 1260 Bin: pump, G1312B, degasser; autosampler; ColCom; DAD G1315C; MSD G6130B ESI; eluent A, acetonitrile; eluent B, 10 $\mathrm{mM}$ ammonium bicarbonate in water (base mode) or $0.1 \%$ formic acid in water (acid mode).

HRMS. HRMS spectra were recorded with a LC-MS Q Exactive Focus spectrometer calibrated with the Pierce calibration solution both in positive and negative modes.

GC/MS. Agilent 6890N, injection S/SL; injector 7683. MS: 5973 MS, EI-positive; carrier gas He.

Analytical SFC. Waters UPC2, Bin pump ACQ-ccBSM; autosampler, column manager, PDA ACQ-PDA; QDA and isocratic pump ACQ-ISM; eluent $\mathrm{A}, \mathrm{CO}_{2}$; eluent $\mathrm{B}, \mathrm{MeOH}+20 \mathrm{mM}$ ammonia.

Preparative SFC. Waters Prep 100 SFC UV/MS directed system; Waters 2998 photodiode array (PDA) detector; Waters Acquity QDa MS detector; Waters 2767 sample manager. Columns: Phenomenex Lux Amylose-1 $(250 \mathrm{~mm} \times 21 \mathrm{~mm}, 5 \mu \mathrm{m})$, Phenomenex Lux Cellulose-1 $(250 \mathrm{~mm} \times 21.2 \mathrm{~mm}, 5 \mu \mathrm{m})$, Phenomenex Lux Cellulose$2(250 \mathrm{~mm} \times 21.2 \mathrm{~mm}, 5 \mu \mathrm{m})$, Diacel Chiralpak IC for SFC $(250 \mathrm{~mm}$ $\times 20 \mathrm{~mm}, 5 \mu \mathrm{m}$ ); column temp $35^{\circ} \mathrm{C}$; flow $70 \mathrm{~mL} / \mathrm{min}$; ABPR 120 bar; eluent $\mathrm{A}, \mathrm{CO}_{2}$; eluent $\mathrm{B}, 20 \mathrm{mM}$ ammonia in methanol. Linear gradient: $t=0 \operatorname{min~} 10 \% \mathrm{~B}, t=5 \mathrm{~min} 50 \% \mathrm{~B} ; t=7.5 \operatorname{min~} 50 \% \mathrm{~B}$. Detection: PDA $(210-400 \mathrm{~nm})$. Fraction collection is based on PDA TIC.

Analytical SFC. Waters UPC2, Bin pump ACQ-ccBSM; autosampler, column manager; PDA ACQ-PDA; QDA and isocratic pump ACQ-ISM. Phenomenex Amylose-1 $(100 \mathrm{~mm} \times 4.6 \mathrm{~mm}, 5$ $\mu \mathrm{m}$ ); column temp $35^{\circ} \mathrm{C}$; flow $2.5 \mathrm{~mL} / \mathrm{min}$; BPR 170 bar; eluent $\mathrm{A}$, $\mathrm{CO}_{2}$; eluent $\mathrm{B}, \mathrm{MeOH}+20 \mathrm{mM}$ ammonia. Linear gradient: $t=0 \mathrm{~min}$ $5 \% \mathrm{~B}, t=5 \min 50 \% \mathrm{~B} ; t=6 \min 50 \% \mathrm{~B}$. Detection: PDA $(210-320$ $\mathrm{nm})$.

MPLC. Preparative base XSelect. Instrument type: Reveleris prep MPLC; column, Waters XSelect CSH C18 $(145 \mathrm{~mm} \times 25 \mathrm{~mm}, 10$ $\mu \mathrm{m}$ ); flow $40 \mathrm{~mL} / \mathrm{min}$; column temp, room temperature; eluent $\mathrm{A}, 10$ $\mathrm{mM}$ ammonium bicarbonate in water $(\mathrm{pH}=9.0)$; eluent $\mathrm{B}, 99 \%$ acetonitrile $+1 \% 10 \mathrm{mM}$ ammonium bicarbonate in water. Gradient: $t=0 \min 5 \% \mathrm{~B}, t=1 \min 5 \% \mathrm{~B}, t=2 \min 30 \% \mathrm{~B}, t=17 \min 70 \% \mathrm{~B}, t$ $=18 \min 100 \% \mathrm{~B}, t=23 \min 100 \%$ B. Detection UV: $220,254,340$ $\mathrm{nm}$.

MPLC. Preparative acid Luna. Instrument type: Reveleris prep MPLC; column, Phenomenex Luna C18(3) (150 mm $\times 25 \mathrm{~mm}, 10$ $\mu \mathrm{m})$; flow $40 \mathrm{~mL} / \mathrm{min}$; column temp, room temperature; eluent $\mathrm{A}$, $0.1 \%(\mathrm{v} / \mathrm{v})$ formic acid in water; eluent $\mathrm{B}, 0.1 \%(\mathrm{v} / \mathrm{v})$ formic acid in acetonitrile. Gradient: $t=0 \min 5 \% \mathrm{~B}, t=1 \min 5 \% \mathrm{~B}, t=2 \min 30 \%$ $\mathrm{B}, t=17 \min 70 \% \mathrm{~B}, t=18 \min 100 \% \mathrm{~B}, t=23 \min 100 \% \mathrm{~B}$. Detection UV: 220, 254, $340 \mathrm{~nm}$, ELSD.

All test compounds were found to be $>95 \%$ pure by LCMS and $\mathrm{H}$ NMR analysis. Intermediates in the synthesis were $>95 \%$ pure unless stated otherwise. 
3-(trans-3-(5-(5-Ethoxypyridin-2-yl)-4-(2-fluorophenyl)-4H1,2,4-triazol-3-yl)cyclobutyl)-1,5-naphthyridine-4-carboxamide (10). The title compound was prepared according to general procedure $\mathrm{F}$ as a white solid (21.4 $\mathrm{mg}, 38 \%$ yield). LC/MS (ESI) $\mathrm{m} / \mathrm{z}$ for $\mathrm{C}_{28} \mathrm{H}_{24} \mathrm{FN}_{7} \mathrm{O}_{2} 509$ (calcd) $510\left([\mathrm{M}+\mathrm{H}]^{+}\right.$, found). ${ }^{1} \mathrm{H}$ NMR (400 $\mathrm{MHz}$, chloroform- $d) \delta 11.31(\mathrm{~d}, J=5.9 \mathrm{~Hz}, 1 \mathrm{H}), 9.14(\mathrm{~d}, J=4.4 \mathrm{~Hz}$, $1 \mathrm{H}), 8.98(\mathrm{dd}, J=4.2,1.8 \mathrm{~Hz}, 1 \mathrm{H}), 8.58-8.52(\mathrm{~m}, 2 \mathrm{H}), 8.17(\mathrm{~d}, J=$ $8.8 \mathrm{~Hz}, 1 \mathrm{H}), 7.88(\mathrm{~d}, J=2.9 \mathrm{~Hz}, 1 \mathrm{H}), 7.74(\mathrm{dd}, J=8.6,4.2 \mathrm{~Hz}, 1 \mathrm{H})$, $7.48-7.40(\mathrm{~m}, 1 \mathrm{H}), 7.26-7.14(\mathrm{~m}, 4 \mathrm{H}), 4.84(\mathrm{~h}, J=6.9 \mathrm{~Hz}, 1 \mathrm{H})$, $4.04(\mathrm{q}, J=7.0 \mathrm{~Hz}, 2 \mathrm{H}), 3.53(\mathrm{tt}, J=10.3,5.6 \mathrm{~Hz}, 1 \mathrm{H}), 3.14-3.02$ $(\mathrm{m}, 2 \mathrm{H}), 2.62-2.48(\mathrm{~m}, 2 \mathrm{H}), 1.40(\mathrm{t}, J=7.0 \mathrm{~Hz}, 3 \mathrm{H})$.

3-(trans-3-(4-(2-Fluorophenyl)-5-(thiazol-2-yl)-4H-1,2,4-triazol-3-yl)cyclobutyl)-1,5-naphthyridine-4-carboxamide (11). The title compound was prepared according to general procedure $\mathrm{F}$ as a white solid (6.6 $\mathrm{mg}, 23 \%$ yield). LC/MS (ESI) $\mathrm{m} / \mathrm{z}$ for $\mathrm{C}_{24} \mathrm{H}_{18} \mathrm{FN}_{7} \mathrm{OS} 471$ (calcd) $472\left([\mathrm{M}+\mathrm{H}]^{+}\right.$, found). ${ }^{1} \mathrm{H}$ NMR (400 $\mathrm{MHz}$, chloroform- $d) \delta 11.33(\mathrm{~d}, J=6.0 \mathrm{~Hz}, 1 \mathrm{H}), 9.15(\mathrm{~d}, J=4.5 \mathrm{~Hz}$, $1 \mathrm{H}), 8.98(\mathrm{dd}, J=4.2,1.8 \mathrm{~Hz}, 1 \mathrm{H}), 8.59-8.52(\mathrm{~m}, 2 \mathrm{H}), 7.75(\mathrm{dd}, J=$ 8.5, $4.2 \mathrm{~Hz}, 1 \mathrm{H}), 7.65(\mathrm{~d}, J=3.2 \mathrm{~Hz}, 1 \mathrm{H}), 7.57-7.47(\mathrm{~m}, 1 \mathrm{H}), 7.37$ $(\mathrm{d}, J=3.2 \mathrm{~Hz}, 1 \mathrm{H}), 7.34-7.22(\mathrm{~m}, 3 \mathrm{H}), 4.92-4.80(\mathrm{~m}, 1 \mathrm{H}), 3.60-$ $3.49(\mathrm{~m}, 1 \mathrm{H}), 3.15-3.02(\mathrm{~m}, 2 \mathrm{H}), 2.68-2.51(\mathrm{~m}, 2 \mathrm{H})$.

3-(trans-3-(4-(2-Fluorophenyl)-5-(5-(methylsulfonyl)pyridin-2-yl)-4H-1,2,4-triazol-3-yl)cyclobutyl)-1,5-naphthyridine-4-carboxamide (12). The title compound was prepared according to general procedure $\mathrm{F}$ as a white solid $(14.8 \mathrm{mg}, 53 \%$ yield). LC/MS (ESI) $m / z$ for $\mathrm{C}_{27} \mathrm{H}_{22} \mathrm{FN}_{7} \mathrm{O}_{3} \mathrm{~S} 543$ (calcd) 544 ([ $[\mathrm{M}+$ $\mathrm{H}]^{+}$found). ${ }^{1} \mathrm{H}$ NMR (400 MHz, chloroform- $d$ ) $\delta 11.31$ (br d, $J=6.1$ $\mathrm{Hz}, 1 \mathrm{H}), 9.15$ (d, $J=4.5 \mathrm{~Hz}, 1 \mathrm{H}), 8.97$ (dd, $J=4.2,1.8 \mathrm{~Hz}, 1 \mathrm{H}), 8.73$ (dd, $J=2.5,0.8 \mathrm{~Hz}, 1 \mathrm{H}$ ), 8.57 (pseudo d, $J=1.6 \mathrm{~Hz}, 1 \mathrm{H}$ ), 8.55 (pseudo d, $J=4.2 \mathrm{~Hz}, 2 \mathrm{H}), 8.29(\mathrm{dd}, J=8.3,2.3 \mathrm{~Hz}, 1 \mathrm{H}), 7.74(\mathrm{dd}, J$ $=8.5,4.2 \mathrm{~Hz}, 1 \mathrm{H}), 7.55-7.46(\mathrm{~m}, 1 \mathrm{H}), 7.30-7.19(\mathrm{~m}, 3 \mathrm{H}), 4.89(\mathrm{~h}, J$ $=7.1 \mathrm{~Hz}, 1 \mathrm{H}), 3.55(\mathrm{tt}, J=10.0,5.5 \mathrm{~Hz}, 1 \mathrm{H}), 3.17-3.02(\mathrm{~m}, 2 \mathrm{H})$, $3.08(\mathrm{~s}, 3 \mathrm{H}), 2.69-2.52(\mathrm{~m}, 2 \mathrm{H})$.

3-(trans-3-(5-(5-Ethoxypyridin-2-yl)-4-(2-fluorophenyl)-4H1,2,4-triazol-3-yl)cyclobutyl)picolinamide (13). The title compound was prepared according to general procedure $\mathrm{F}$ as a white solid ( $16.8 \mathrm{mg}, 46 \%$ yield). LC/MS (ESI) $m / z$ for $\mathrm{C}_{25} \mathrm{H}_{23} \mathrm{FN}_{6} \mathrm{O}_{2}=458$ (calculated), $459\left([\mathrm{M}+\mathrm{H}]^{+}\right.$, found). ${ }^{1} \mathrm{H}$ NMR $(400 \mathrm{MHz}$, chloroform- $d$ ) $\delta 8.53(\mathrm{dt}, J=4.7,1.3 \mathrm{~Hz}, 1 \mathrm{H}), 8.21(\mathrm{~d}, J=7.0 \mathrm{~Hz}$, $1 \mathrm{H}), 8.19-8.12(\mathrm{~m}, 2 \mathrm{H}), 7.88(\mathrm{~d}, J=2.8 \mathrm{~Hz}, 1 \mathrm{H}), 7.83(\mathrm{td}, J=7.7$, $1.7 \mathrm{~Hz}, 1 \mathrm{H}), 7.48-7.38(\mathrm{~m}, 2 \mathrm{H}), 7.24-7.15(\mathrm{~m}, 4 \mathrm{H}), 4.76(\mathrm{~h}, J=7.0$ $\mathrm{Hz}, 1 \mathrm{H}), 4.04(\mathrm{q}, J=6.9 \mathrm{~Hz}, 2 \mathrm{H}), 3.47(\mathrm{tt}, J=10.0,5.1 \mathrm{~Hz}, 1 \mathrm{H})$, $3.09-2.97(\mathrm{~m}, 2 \mathrm{H}), 2.52-2.36(\mathrm{~m}, 2 \mathrm{H}), 1.40(\mathrm{t}, J=7.0 \mathrm{~Hz}, 3 \mathrm{H})$. HRMS $459.19393\left([\mathrm{M}+\mathrm{H}]^{+}\right.$, calculated $), 459.19353\left([\mathrm{M}+\mathrm{H}]^{+}\right.$, found), $\Delta=-0.87 \mathrm{ppm}$.

3-(trans-3-(4-(2-Fluorophenyl)-5-(thiazol-2-yl)-4H-1,2,4-triazol-3-yl)cyclobutyl)picolinamide (14). The title compound was prepared according to general procedure $\mathrm{F}$ as a white solid $(21.3 \mathrm{mg}$, $84 \%$ yield). LC/MS (ESI) $m / z$ for $\mathrm{C}_{21} \mathrm{H}_{17} \mathrm{FN}_{6} \mathrm{OS} 420$ (calcd) 421 $\left([\mathrm{M}+\mathrm{H}]^{+}\right.$, found). ${ }^{1} \mathrm{H}$ NMR $(400 \mathrm{MHz}$, chloroform- $d) \delta 8.53(\mathrm{dq}, J$ $=4.5,0.9 \mathrm{~Hz}, 1 \mathrm{H}), 8.23(\mathrm{br} \mathrm{d}, J=7.0 \mathrm{~Hz}, 1 \mathrm{H}), 8.17(\mathrm{dt}, J=7.8,1.1$ $\mathrm{Hz}, 1 \mathrm{H}), 7.84(\mathrm{td}, J=7.7,1.7 \mathrm{~Hz}, 1 \mathrm{H}), 7.64(\mathrm{~d}, J=3.2 \mathrm{~Hz}, 1 \mathrm{H})$, $7.57-7.49(\mathrm{~m}, 1 \mathrm{H}), 7.43(\mathrm{ddd}, J=7.8,4.7,1.3 \mathrm{~Hz}, 1 \mathrm{H}), 7.37(\mathrm{~d}, J=$ $3.2 \mathrm{~Hz}, 1 \mathrm{H}), 7.33-7.27(\mathrm{~m}, 2 \mathrm{H}), 7.26-7.21(\mathrm{~m}, 1 \mathrm{H}), 4.78(\mathrm{~h}, J=7.0$ $\mathrm{Hz}, 1 \mathrm{H}), 3.54-3.43(\mathrm{~m}, 1 \mathrm{H}), 3.11-2.96(\mathrm{~m}, 2 \mathrm{H}), 2.56-2.39(\mathrm{~m}$, $2 \mathrm{H})$. HRMS $421.12413\left([\mathrm{M}+\mathrm{H}]^{+}\right.$, calculated $), 421.12330([\mathrm{M}+$ $\mathrm{H}]^{+}$, found), $\Delta=-0.84 \mathrm{ppm}$.

3-(trans-3-(4-(2-Fluorophenyl)-5-(5-(methylsulfonyl)pyridin-2-yl)-4H-1,2,4-triazol-3-yl)cyclobutyl)picolinamide (15). The title compound was prepared according to general procedure $\mathrm{F}$ as a white solid $(6.1 \mathrm{mg}, 40 \%$ yield). LC/MS (ESI) $\mathrm{m} / z$ for $\mathrm{C}_{24} \mathrm{H}_{21} \mathrm{FN}_{6} \mathrm{O}_{3} \mathrm{~S} 492$ (calcd) $493\left([\mathrm{M}+\mathrm{H}]^{+}\right.$found). ${ }^{1} \mathrm{H}$ NMR $(400 \mathrm{MHz}$, chloroform- $d) \delta 8.72(\mathrm{~d}, J=2.3 \mathrm{~Hz}, 1 \mathrm{H}), 8.58-8.51(\mathrm{~m}$, $2 \mathrm{H}), 8.28(\mathrm{dd}, J=8.4,2.3 \mathrm{~Hz}, 1 \mathrm{H}), 8.23(\mathrm{br} \mathrm{d}, J=7.0 \mathrm{~Hz}, 1 \mathrm{H}), 8.17$ $(\mathrm{dt}, J=7.7,1.1 \mathrm{~Hz}, 1 \mathrm{H}), 7.84(\mathrm{td}, J=7.7,1.7 \mathrm{~Hz}, 1 \mathrm{H}), 7.55-7.47(\mathrm{~m}$, $1 \mathrm{H}), 7.43$ (ddd, $J=7.6,4.8,1.2 \mathrm{~Hz}, 1 \mathrm{H}), 7.29-7.17(\mathrm{~m}, 3 \mathrm{H}), 4.80$ (h, $J=7.1 \mathrm{~Hz}, 1 \mathrm{H}), 3.53-3.44(\mathrm{~m}, 1 \mathrm{H}), 3.07(\mathrm{~s}, 3 \mathrm{H}), 3.14-2.97(\mathrm{~m}$, $2 \mathrm{H}), 2.57-2.40(\mathrm{~m}, 2 \mathrm{H})$.

3-(trans-3-(4-(2-Fluorophenyl)-5-(5-(methylsulfonyl)pyridin-2-yl)-4H-1,2,4-triazol-3-yl)cyclobutyl)quinoline-8-carboxamide (16). The title compound was prepared according to general procedure $\mathrm{F}$ as a white solid $(24.9 \mathrm{mg}, 91 \%$ yield). LC/MS (ESI) $\mathrm{m} / z$ for $\mathrm{C}_{28} \mathrm{H}_{23} \mathrm{FN}_{6} \mathrm{O}_{3} \mathrm{~S}=542$ (calculated), $543\left([\mathrm{M}+\mathrm{H}]^{+}\right.$ found). ${ }^{1} \mathrm{H}$ NMR $(400 \mathrm{MHz}$, chloroform- $d) \delta 11.56(\mathrm{~d}, J=5.8 \mathrm{~Hz}$, $1 \mathrm{H}), 8.91(\mathrm{dd}, J=4.3,1.8 \mathrm{~Hz}, 1 \mathrm{H}), 8.83(\mathrm{dd}, J=7.4,1.6 \mathrm{~Hz}, 1 \mathrm{H})$, $8.73(\mathrm{~d}, J=2.3 \mathrm{~Hz}, 1 \mathrm{H}), 8.56(\mathrm{~d}, J=8.4 \mathrm{~Hz}, 1 \mathrm{H}), 8.28(\mathrm{dt}, J=8.4$, $2.5 \mathrm{~Hz}, 2 \mathrm{H}), 7.96(\mathrm{dd}, J=8.1,1.6 \mathrm{~Hz}, 1 \mathrm{H}), 7.67(\mathrm{t}, J=7.7 \mathrm{~Hz}, 1 \mathrm{H})$, $7.49(\mathrm{dt}, J=8.3,5.0 \mathrm{~Hz}, 2 \mathrm{H}), 7.26-7.18(\mathrm{~m}, 3 \mathrm{H}), 4.85$ (apparent dq, $J=13.4,6.8 \mathrm{~Hz}, 1 \mathrm{H}$ ), 3.57 (apparent tt, $J=10.1,5.8 \mathrm{~Hz}, 1 \mathrm{H}$ ), $3.16-$ $3.01(\mathrm{~m}, 2 \mathrm{H}), 3.08(\mathrm{~s}, 3 \mathrm{H}), 2.67-2.50(\mathrm{~m}, 2 \mathrm{H})$. HRMS 543.16091 $\left([\mathrm{M}+\mathrm{H}]^{+}\right.$, calculated $), 543.16007\left([\mathrm{M}+\mathrm{H}]^{+}\right.$, found $), \Delta=-0.84$ ppm.

3-(trans-3-(4-(2-Chlorophenyl)-5-(pyrimidin-4-yl)-4H-1,2,4triazol-3-yl)cyclobutyl)-2-oxo-2,3-dihydrobenzo[d]oxazole-6carbonitrile (18). Crude hydroxybenzonitrile (8) (10 mg, 0.014 $\mathrm{mmol}, \sim 60 \%$ pure) was dissolved in DCM (dried, $3.0 \mathrm{~mL}$ ) under a nitrogen atmosphere. Acetonitrile (anhydrous, $1.0 \mathrm{~mL}$ ) was also added followed by CDI $(11 \mathrm{mg}, 0.070 \mathrm{mmol})$, and the mixture was stirred for $60 \mathrm{~h}$ at ambient temperature. The solvent was evaporated, and the residue was purified by preparative SFC. After freeze-drying the purified fractions from acetonitrile/water, $2.8 \mathrm{mg}$ ( $42 \%$ yield) of a white powder of the target compound (18) was obtained. LC/MS (ESI) $\mathrm{m} / z$ for $\mathrm{C}_{24} \mathrm{H}_{16} \mathrm{ClN}_{7} \mathrm{O}_{2}=469 / 471$ (calculated), 470/472 ([M $+\mathrm{H}]^{+}$, found). ${ }^{1} \mathrm{H}$ NMR (400 MHz, chloroform- $d$ ) $\delta$ 8.86-8.82 (m, $2 \mathrm{H}), 8.28(\mathrm{dd}, J=5.3,1.2 \mathrm{~Hz}, 1 \mathrm{H}), 7.60-7.50(\mathrm{~m}, 3 \mathrm{H}), 7.51-7.42$ (m, $2 \mathrm{H}), 7.30$ (dd, $J=7.8,1.4 \mathrm{~Hz}, 1 \mathrm{H}), 7.18(\mathrm{~d}, J=8.2 \mathrm{~Hz}, 1 \mathrm{H}), 5.20$ $(\mathrm{p}, J=8.3 \mathrm{~Hz}, 1 \mathrm{H}), 3.44-3.34(\mathrm{~m}, 2 \mathrm{H}), 3.34-3.25(\mathrm{~m}, 1 \mathrm{H}), 2.98(\mathrm{td}$, $J=8.5,4.1 \mathrm{~Hz}, 1 \mathrm{H}), 2.93-2.83(\mathrm{~m}, 1 \mathrm{H})$.

1-(3-(4-(2-Chlorophenyl)-5-(pyrimidin-4-yl)-4H-1,2,4-triazol-3-yl)bicyclo[1.1.1]pentan-1-yl)-2-oxo-2,3-dihydro-1Hbenzo[ $d]$ imidazole-5-carbonitrile (19). Under a nitrogen atmosphere an impure batch of 3-amino-4-((3-(4-(2-chlorophenyl)-5(pyrimidin-4-yl)-4H-1,2,4-triazol-3-yl)bicyclo[1.1.1]pentan-1-yl)amino)benzonitrile 19b (36 mg, $0.060 \mathrm{mmol}, \sim 75 \%$ pure; see Supporting Information) was dissolved in dry DCM $(6.0 \mathrm{~mL})$, and it was treated at ambient temperature with several portions of CDI (in total 9 equiv) over a period of $24 \mathrm{~h}$ until the complete conversion was reached. The mixture was evaporated to dryness and the residue was first flashed on a $12 \mathrm{~g}$ silica gel cartridge eluted with a gradient of methanol ( $0 \%$ via $3 \%$ to $10 \%)$ in DCM. Then it was submitted to purification by preparative SFC isolating $19.0 \mathrm{mg}$ (65\% yield) of a white powder. LC/MS (ESI) $m / z$ for $\mathrm{C}_{25} \mathrm{H}_{17} \mathrm{ClN}_{8} \mathrm{O}=480 / 482$ (calculated), 481/483 $\left([\mathrm{M}+\mathrm{H}]^{+}\right.$, found). ${ }^{1} \mathrm{H}$ NMR $(400 \mathrm{MHz}$, DMSO- $\left.d_{6}\right) \delta 11.36(\mathrm{~s}, 1 \mathrm{H}), 8.95(\mathrm{~d}, J=5.3 \mathrm{~Hz}, 1 \mathrm{H}), 8.90(\mathrm{~d}, J=1.2$ $\mathrm{Hz}, 1 \mathrm{H}), 8.23(\mathrm{dd}, J=5.3,1.3 \mathrm{~Hz}, 1 \mathrm{H}), 7.79(\mathrm{dd}, J=7.8,1.5 \mathrm{~Hz}$, $1 \mathrm{H}), 7.76(\mathrm{dd}, J=8.0,1.2 \mathrm{~Hz}, 1 \mathrm{H}), 7.66(\mathrm{td}, J=7.8,1.6 \mathrm{~Hz}, 1 \mathrm{H})$, $7.58(\mathrm{td}, J=7.6,1.3 \mathrm{~Hz}, 1 \mathrm{H}), 7.44(\mathrm{dd}, J=8.3,1.4 \mathrm{~Hz}, 1 \mathrm{H}), 7.40-$ $7.30(\mathrm{~m}, 2 \mathrm{H}), 2.61-2.52(\mathrm{~m}$-distorted $\mathrm{q}, 6 \mathrm{H})$. HRMS 481.12866 ([M $+\mathrm{H}]^{+}$, calculated $), 481.12796\left([\mathrm{M}+\mathrm{H}]^{+}\right.$, found $), \Delta=-1.46 \mathrm{ppm}$. 3-(trans-3-(4-(2-Chlorophenyl)-5-(pyrimidin-4-yl)-4H-1,2,4triazol-3-yl)cyclobutyl)picolinamide (20). The title compound was prepared according to general procedure $\mathrm{F}$ and obtained as a white solid (41.1 mg, 94\% yield). LC/MS (ESI) $\mathrm{m} / z$ for $\mathrm{C}_{22} \mathrm{H}_{18} \mathrm{ClN}_{7} \mathrm{O}=431 / 433$ (calculated), 432/434 $\left([\mathrm{M}+\mathrm{H}]^{+}\right.$, found). ${ }^{1} \mathrm{H}$ NMR (400 MHz, chloroform-d) $\delta 8.82(\mathrm{~s}, 1 \mathrm{H}), 8.81$ $(\mathrm{d}, J=3.3 \mathrm{~Hz}, 1 \mathrm{H}), 8.53(\mathrm{qd}, J=4.8,0.6 \mathrm{~Hz}, 1 \mathrm{H}), 8.28(\mathrm{dd}, J=5.3$, $1.3 \mathrm{~Hz}, 1 \mathrm{H}), 8.23(\mathrm{~d}, J=6.6 \mathrm{~Hz}, 1 \mathrm{H}), 8.17(\mathrm{~d}, J=7.8 \mathrm{~Hz}, 1 \mathrm{H}), 7.84$ $(\mathrm{td}, J=7.7,1.7 \mathrm{~Hz}, 1 \mathrm{H}), 7.54(\mathrm{dd}, J=8.0,1.5 \mathrm{~Hz}, 1 \mathrm{H}), 7.49(\mathrm{td}, J=$ 7.7, $1.6 \mathrm{~Hz}, 1 \mathrm{H}), 7.46-7.38(\mathrm{~m}, 2 \mathrm{H}), 7.30(\mathrm{dd}, J=7.8,1.5 \mathrm{~Hz}, 1 \mathrm{H})$, 4.86-4.72 (m, 1H), 3.49-3.36 (m, 1H), 3.11-3.00 (m, 2H), 2.53$2.38(\mathrm{~m}, 2 \mathrm{H})$. HRMS $432.13341\left([\mathrm{M}+\mathrm{H}]^{+}\right.$, calculated $), 432.13272$ $\left([\mathrm{M}+\mathrm{H}]^{+}\right.$, found $), \Delta=-1.61 \mathrm{ppm}$.

3-(trans-3-(4-(2-Chlorophenyl)-5-(pyrimidin-4-yl)-4H-1,2,4triazol-3-yl)cyclobutyl)-1,5-naphthyridine-4-carboxamide (21). The title compound was prepared according to general procedure $\mathrm{F}$ and obtained as a white solid $(12.7 \mathrm{mg}, 26 \%$ yield). LC/MS (ESI) $m / z$ for $\mathrm{C}_{25} \mathrm{H}_{19} \mathrm{ClN}_{8} \mathrm{O}=482 / 484$ (calculated), 483/ $485\left([\mathrm{M}+\mathrm{H}]^{+}\right.$, found). ${ }^{1} \mathrm{H}$ NMR $(400 \mathrm{MHz}$, chloroform- $d) \delta 11.32$ $(\mathrm{d}, J=5.8 \mathrm{~Hz}, 1 \mathrm{H}), 9.15(\mathrm{~d}, J=4.4 \mathrm{~Hz}, 1 \mathrm{H}), 8.98(\mathrm{dd}, J=4.2,1.7 \mathrm{~Hz}$, $1 \mathrm{H}), 8.85-8.79(\mathrm{~m}, 2 \mathrm{H}), 8.60-8.52(\mathrm{~m}, 2 \mathrm{H}), 8.29(\mathrm{dd}, J=5.3,1.3$ $\mathrm{Hz}, 1 \mathrm{H}), 7.75(\mathrm{dd}, J=8.5,4.2 \mathrm{~Hz}, 1 \mathrm{H}), 7.54(\mathrm{dd}, J=7.9,1.5 \mathrm{~Hz}$, 
$1 \mathrm{H}), 7.48(\mathrm{td}, J=7.7,1.6 \mathrm{~Hz}, 1 \mathrm{H}), 7.42(\mathrm{td}, J=7.6,1.6 \mathrm{~Hz}, 1 \mathrm{H}), 7.32$ (dd, $J=7.8,1.5 \mathrm{~Hz}, 1 \mathrm{H}), 4.88(\mathrm{~h}, J=7.2 \mathrm{~Hz}, 1 \mathrm{H}), 3.49$ (tt, $J=9.7$, $5.4 \mathrm{~Hz}, 1 \mathrm{H}), 3.17-3.04(\mathrm{~m}, 2 \mathrm{H}), 2.65-2.50(\mathrm{~m}, 2 \mathrm{H})$. HRMS $483.14431\left([\mathrm{M}+\mathrm{H}]^{+}\right.$, calculated $), 483.14350\left([\mathrm{M}+\mathrm{H}]^{+}\right.$, found $), \Delta$ $=-0.81 \mathrm{ppm}$.

3-(trans-3-(4-(2-Chlorophenyl)-5-(5-ethoxypyridin-2-yl)-4H1,2,4-triazol-3-yl)cyclobutyl)-2-oxo-2,3-dihydro-1 $H$-benzo[d]imidazole-5-carbonitrile (22). The title compound was prepared according to general procedure $\mathrm{D}$ from $(1 r, 3 r)$-3-(5-cyano-2-oxo-2,3dihydro-1H-benzo[d]imidazol-1-yl)cyclobutane-1-carbohydrazide $2^{11}$ (60.2 $\mathrm{mg}, 0.222 \mathrm{mmol}$ ) and methyl $\mathrm{N}$-(2-chlorophenyl)-5-ethoxypyridine-2-carbimidothioate $\mathbf{E 2}(68 \mathrm{mg}, 0.222 \mathrm{mmol})$ affording $49.9 \mathrm{mg}$ (42\% yield) of a white solid. LC/MS (ESI) $m / z$ for $\mathrm{C}_{27} \mathrm{H}_{22} \mathrm{ClN}_{7} \mathrm{O}_{2}=$ 511 (calculated), $512\left([\mathrm{M}+\mathrm{H}]^{+}\right.$, found). ${ }^{1} \mathrm{H}$ NMR $(400 \mathrm{MHz}$, chloroform- $d) \delta 8.69(\mathrm{~s}, 1 \mathrm{H}), 8.17(\mathrm{~d}, J=8.8 \mathrm{~Hz}, 1 \mathrm{H}), 7.87(\mathrm{~d}, J=$ $2.8 \mathrm{~Hz}, 1 \mathrm{H}$ ), 7.51 (distorted dd, $J=7.8,1.8 \mathrm{~Hz}, 1 \mathrm{H}$ ), 7.46 (td, $J=7.6$, $1.8 \mathrm{~Hz}, 1 \mathrm{H}), 7.44-7.38(\mathrm{~m}, 2 \mathrm{H}), 7.31$ (distorted dd, $J=7.7,1.7 \mathrm{~Hz}$, $2 \mathrm{H}), 7.25-7.18(\mathrm{~m}, 2 \mathrm{H}), 5.28(\mathrm{t}, J=8.4 \mathrm{~Hz}, 1 \mathrm{H}), 4.04(\mathrm{q}, J=7.0 \mathrm{~Hz}$, $2 \mathrm{H}), 3.45-3.29(\mathrm{~m}, 3 \mathrm{H}), 3.00-2.84(\mathrm{~m}, 2 \mathrm{H}), 1.40(\mathrm{t}, J=7.0 \mathrm{~Hz}$, $3 \mathrm{H})$. HRMS 512.15963 $\left([\mathrm{M}+\mathrm{H}]^{+}\right.$, calculated $), 512.15900([\mathrm{M}+$ $\mathrm{H}]^{+}$, found), $\Delta=-1.23 \mathrm{ppm}$.

3-(trans-3-(4-(2-Fluorophenyl)-5-(pyrimidin-4-yl)-4H-1,2,4triazol-3-yl)cyclobutyl)-2-oxo-2,3-dihydro-1 H-benzo[d]imidazole-5-carbonitrile (23). The title compound was prepared according to general procedure $\mathrm{D}$ from $(1 r, 3 r)$-3-(5-cyano-2-oxo-2,3dihydro- $1 H$-benzo[d]imidazol-1-yl)cyclobutane-1-carbohydrazide $2^{11}$ (43.9 $\mathrm{mg}, 0.162 \mathrm{mmol}$ ) and methyl $\mathrm{N}$-(2-fluorophenyl)pyrimidine-4carbimidothioate $\mathbf{E} 3(40 \mathrm{mg}, 0.162 \mathrm{mmol})$ as a white powder $(14 \mathrm{mg}$, $19 \%$ yield). LC/MS (ESI) $m / z$ for $\mathrm{C}_{24} \mathrm{H}_{17} \mathrm{FN}_{8} \mathrm{O}=452$ (calculated), $453\left([\mathrm{M}+\mathrm{H}]^{+}\right.$, found). ${ }^{1} \mathrm{H}$ NMR $(400 \mathrm{MHz}$, chloroform- $d) \delta 8.87$ $(\mathrm{d}, J=1.4 \mathrm{~Hz}, 1 \mathrm{H}), 8.85(\mathrm{~d}, J=5.2 \mathrm{~Hz}, 1 \mathrm{H}), 8.71(\mathrm{br} \mathrm{s}, 1 \mathrm{H}), 8.29$ $(\mathrm{dd}, J=5.3,1.4 \mathrm{~Hz}, 1 \mathrm{H}), 7.61-7.53(\mathrm{~m}, 1 \mathrm{H}), 7.43(\mathrm{dd}, J=8.3,1.5$ $\mathrm{Hz}, 1 \mathrm{H}), 7.35-7.29(\mathrm{~m}, 2 \mathrm{H}), 7.26-7.22(\mathrm{~m}, 2 \mathrm{H}), 7.19(\mathrm{~d}, J=8.3 \mathrm{~Hz}$, $1 \mathrm{H}), 5.27(\mathrm{p}, J=8.7 \mathrm{~Hz}, 1 \mathrm{H}), 3.54-3.44(\mathrm{~m}, 2 \mathrm{H}), 3.39$ (apparent $\mathrm{q}, J$ $=10.3 \mathrm{~Hz}, 1 \mathrm{H}), 3.05-2.97(\mathrm{~m}, 1 \mathrm{H}), 2.88-2.78(\mathrm{~m}, 1 \mathrm{H})$. HRMS 453.15821 $\left([\mathrm{M}+\mathrm{H}]^{+}\right.$, calculated $), 453.15769\left([\mathrm{M}+\mathrm{H}]^{+}\right.$, found $), \Delta$ $=-1.16 \mathrm{ppm}$.

3-(trans-3-(4-(2-Fluorophenyl)-5-(pyridin-2-yl)-4H-1,2,4-triazol-3-yl)cyclobutyl)-7-fluoro-1,5-naphthyridine-4-carboxamide (27). The title compound was prepared according to general procedure $\mathrm{F}$ as a white solid $(17.2 \mathrm{mg}, 70 \%$ yield). LC/MS (ESI) $\mathrm{m} / \mathrm{z}$ for $\mathrm{C}_{26} \mathrm{H}_{19} \mathrm{~F}_{2} \mathrm{~N}_{7} \mathrm{O}=483$ (calculated), $484\left([\mathrm{M}+\mathrm{H}]^{+}\right.$, found). ${ }^{1} \mathrm{H}$ NMR (400 MHz, chloroform- $d) \delta 10.83(\mathrm{~d}, J=6.0 \mathrm{~Hz}, 1 \mathrm{H}), 9.15(\mathrm{~d}$, $J=4.5 \mathrm{~Hz}, 1 \mathrm{H}), 8.91(\mathrm{~d}, J=2.8 \mathrm{~Hz}, 1 \mathrm{H}), 8.52(\mathrm{~d}, J=4.4 \mathrm{~Hz}, 1 \mathrm{H})$, $8.26(\mathrm{dt}, J=7.9,1.0 \mathrm{~Hz}, 1 \mathrm{H}), 8.24-8.16(\mathrm{~m}, 2 \mathrm{H}), 7.77(\mathrm{td}, J=7.8$, $1.8 \mathrm{~Hz}, 1 \mathrm{H}), 7.50-7.42(\mathrm{~m}, 1 \mathrm{H}), 7.25-7.15(\mathrm{~m}, 4 \mathrm{H}), 4.87$ (ht, $J=$ $6.8,1.6 \mathrm{~Hz}, 1 \mathrm{H}$ ), $3.53(\mathrm{tt}, J=9.3,5.6 \mathrm{~Hz}, 1 \mathrm{H}$ ), 3.15-3.02 (sym. m, $2 \mathrm{H}), 2.63-2.47$ (sym. m, 2H). HRMS $484.16919\left([\mathrm{M}+\mathrm{H}]^{+}\right.$, calculated), $484.16833\left([\mathrm{M}+\mathrm{H}]^{+}\right.$, found $), \Delta=-1.78 \mathrm{ppm}$.

Preparation of 3-(trans-3-(4-(2-Chlorophenyl)-5-(pyrimidin4-yl)-4H-1,2,4-triazol-3-yl)cyclobutyl)isoindolin-1-one (51). 2Formylbenzoic acid (9) $(33 \mathrm{mg}, 0.22 \mathrm{mmol})$ was suspended in DCM (dry, $1.0 \mathrm{~mL}$ ) under a nitrogen atmosphere, and a solution of trans-3(4-(2-chlorophenyl)-5-(pyrimidin-4-yl)-4H-1,2,4-triazol-3-yl)cyclobutan-1-amine $(\mathbf{G a})(0.20 \mathrm{mmol})$ in acetonitrile (anhydrous, 1.0 $\mathrm{mL})$ and acetic acid $(13 \mu \mathrm{L}, 0.22 \mathrm{mmol})$ were added. The resulting solution was stirred for $17 \mathrm{~h}$ at ambient temperature. Then, two portions of sodium triacetoxyborohydride (each of $85 \mathrm{mg}, 0.40$ mmol) were added and the mixture was stirred for $3 \mathrm{~h}$ at ambient temperature. Extra methanol was added (extra dry, $1.0 \mathrm{~mL}$ ) for better dissolution. The mixture was then heated at $50{ }^{\circ} \mathrm{C}$ overnight for $40 \mathrm{~h}$ while two extra portions of sodium triacetoxyborohydride were added (each of $85 \mathrm{mg}, 0.40 \mathrm{mmol}$ ). The mixture was evaporated to dryness, and the residue was quenched with water and a few $\mathrm{mL}$ of $1 \mathrm{~N}$ aqueous $\mathrm{HCl}$. DCM was added, the aqueous phase was basified with aqueous sodium bicarbonate, and the crude product was extracted with DCM (three times). The extracts were dried over sodium sulfate, filtered, and evaporated to dryness. The crude material was purified on a $12 \mathrm{~g}$ silica gel cartridge eluted with a gradient of methanol ( $0 \%$ to $5 \%)$ in DCM. The product fraction was lyophilized from acetonitrile/ water providing a white powder $(34.1 \mathrm{mg}, 38 \%$ yield) of the target compound. LC/MS (ESI) $m / z$ for $\mathrm{C}_{24} \mathrm{H}_{19} \mathrm{ClN}_{6} \mathrm{O}=442 / 444$ (calculated) $443 / 445\left([\mathrm{M}+\mathrm{H}]^{+}\right.$, found). ${ }^{1} \mathrm{H}$ NMR $(400 \mathrm{MHz}$, chloroform- $d$ ) $\delta 8.86-8.78(\mathrm{~m}, 2 \mathrm{H}), 8.29(\mathrm{dd}, J=5.3,1.2 \mathrm{~Hz}, 1 \mathrm{H})$, $7.81(\mathrm{~d}, J=7.4 \mathrm{~Hz}, 1 \mathrm{H}), 7.58-7.47(\mathrm{~m}, 3 \mathrm{H}), 7.47-7.39(\mathrm{~m}, 3 \mathrm{H})$, $5.09(\mathrm{p}, J=8.2 \mathrm{~Hz}, 1 \mathrm{H}), 4.44(\mathrm{~s}, 2 \mathrm{H}), 3.42-3.31(\mathrm{~m}, 1 \mathrm{H}), 2.98-2.80$ (m, 4H).

Separation of Atropisomers of 1 and Investigation of Their Interconversion. An amount of $40 \mathrm{mg}$ of racemic $1^{11}$ ( $40 \mathrm{mg}$, 0.085 $\mathrm{mmol}$ ) was separated into pure atropisomers by preparative chiral SFC (see Supporting Information) providing, respectively, 16.1 and $11.8 \mathrm{mg}$ of off-white solids. Two sets of two samples dissolved in an acetonitrile/methanol mixture were prepared for each atropisomers. One set was heated in a reaction block at $70{ }^{\circ} \mathrm{C}$, while the other was kept at ambient temperature. Samples were analyzed after 24,48 , and $72 \mathrm{~h}$ to check for the interconversion of atropisomers. After $24 \mathrm{~h}$ no interconversion was observed at ambient temperature, while at $70{ }^{\circ} \mathrm{C}$ $2.5 \%$ of the opposite isomers were detected in both samples. After 48 $\mathrm{h}$ of heating about $5-6 \%$ interconversion was observed at $70{ }^{\circ} \mathrm{C}$. After $72 \mathrm{~h}$, the isomers showed no interconversion at ambient temperature, whereas at $70{ }^{\circ} \mathrm{C}$ about $8-9 \%$ of the other atropisomer was observed by chiral SFC.

Biochemical Assays. Human tankyrase active constructs for TNKS1 (residues 1030-1317) and TNKS2 (residues 873-1162) and other ARTD/PARP enzymes used in the assays were expressed and purified as previously described. ${ }^{34,35}$ The enzymatic assay is based on the measurement of unreacted $\mathrm{NAD}^{+}$, which is chemically converted into a fluorescent compound. ${ }^{36}$ The fluorescence intensity was measured with excitation/emission wavelengths of 372 and 444 nm, respectively, using Tecan Infinity M1000 Pro. The compounds were prepared in half log dilution series and the reactions were done in quadruplicates with protein and compound controls to exclude the effect of compound autofluorescence. All reactions were done at ambient temperature. $20 \mathrm{nM}$ TNKS1 or $5 \mathrm{nM}$ TNKS2 was incubated for $20 \mathrm{~h}$ in assay buffer (50 mM BTP, pH 7.0, $0.5 \mathrm{mM}$ TCEP, $0.01 \%$ Triton-X100) with compound and $10 \mu \mathrm{M}$ or $500 \mathrm{nM} \mathrm{NAD}$, respectively. $5 \mathrm{nM}$ ARTD1/PARP1 or $20 \mathrm{nM}$ ARTD2/PARP2 was incubated for 30 min with compound and $500 \mathrm{nM} \mathrm{NAD}{ }^{+}$in assay buffer ( $50 \mathrm{mM}$ Tris, $\mathrm{pH} 8.0,5 \mathrm{mM} \mathrm{MgCl} 2,10 \mu \mathrm{g} / \mathrm{mL}$ activated DNA) supplemented with 0.2 or $0.1 \mathrm{mg} / \mathrm{mL}$ BSA, respectively. For ARTD3/ PARP3, $20 \mathrm{nM}$ enzyme was incubated for $4 \mathrm{~h}$ with compound and $500 \mathrm{nM} \mathrm{NAD}^{+}$in assay buffer (50 mM PIPES, pH 7.0, $5 \mathrm{mM} \mathrm{MgCl}_{2}$, $20 \mu \mathrm{g} / \mathrm{mL}$ activated DNA, $0.2 \mathrm{mg} / \mathrm{mL}$ BSA). The assay conditions for the other ARTD enzymes were used as previously described. ${ }^{37}$

WNT/ $\beta$-Catenin in Signaling Reporter Assay. The luciferasebased $\mathrm{WNT} / \beta$-catenin signaling pathway reporter assay in human HEK293 cells, as well as $\mathrm{IC}_{50}$ and $\mathrm{GI}_{50} / \mathrm{GI}_{25}$ calculations, was performed as previously described. ${ }^{9}$

In vitro ADME assays. Kinetic solubility assay was performed following standard protocols of Mercachem. The following assays were performed according to the standard protocols of Cyprotex: Caco-2 permeability, dog microsomal stability, hepatocyte stability (human, mouse, dog, rat, and cynomolgus), CYP3A4 inhibition, mouse plasma stability, mouse plasma protein binding, and Ames test.

Microsomal Stability Assay. Test compounds in DMSO (10 $\mathrm{mM}$ ) were further diluted to $100 \mu \mathrm{M}$ in acetonitrile. Human or mouse liver microsomes (BioIVT) from selected species are incubated in duplicate with the test compound at a final concentration of $1 \mu \mathrm{M}$ in $0.1 \mathrm{M}$ potassium phosphate buffer ( $\mathrm{pH} 7.4)$ containing $3.3 \mathrm{mM}$ $\mathrm{MgCl}_{2}, 0.5 \mathrm{mg} / \mathrm{mL}$ microsomal protein, in the presence or absence of NADPH $(1 \mathrm{mM})$. Incubations were performed at $37{ }^{\circ} \mathrm{C}$ in a total volume of $500 \mu \mathrm{L}$. Control incubations with reference substances were included for each experiment. At $t=0,5,15,30,45 \mathrm{~min}$, an amount of $50 \mu \mathrm{L}$ of the incubation mixture was transferred to a quench plate containing acetonitrile and internal standard $(200 \mathrm{nM}$ labetalol) cooled at $4{ }^{\circ} \mathrm{C}$. After the last time point, the quench plates are mixed thoroughly and centrifuged for $15 \mathrm{~min}$ at $3700 \mathrm{rpm}$ and 10 ${ }^{\circ} \mathrm{C}$ (Eppendorf 5804R). The supernatant was transferred to a 96-well plate and analyzed by LCMS (Vanquish Horizon UHPLC equipped with a diode array detector coupled to a Q Exactive focus hybrid 
quadrupole-Orbitrap mass spectrometer). The metabolic stability is evaluated by plotting the natural logarithm of the percentage test compound remaining versus time and performing linear regression.

Safety Panel and hERG Inhibition. Inhibition of 44 selected targets $(n=2)$ including hERG (SafetyScreen 44) using $10 \mu \mathrm{M} 13$ was performed by Eurofins (Cerep-Panlabs).

Mouse Pharmacokinetical Analysis. The pharmacokinetical analyses in mice were performed according to the standard protocols of Medicilon and, as previously described, ${ }^{9}$ using 3 animals per treatment group using 5\% DMSO, 50\% PEG400 (both SigmaAldrich) and $45 \%$ saline as vehicle.

Crystallography. Compounds 105, 13, 10, 106, 107, 87, 88 (Supplementary Table 4) were cocrystallized with the catalytic domain of human TNKS2 (residues 952-1161) in the presence of chymotrypsin (1:100) based on crystallization efforts previously described. ${ }^{11,20}$ Protein $(0.2 \mathrm{mM}, 5.6 \mathrm{mg} / \mathrm{mL})$ was mixed with $0.4 \mathrm{mM}$ compound from a $10 \mathrm{mM}$ DMSO stock solution. The crystallization was set up at $22{ }^{\circ} \mathrm{C}$ using sitting-drop vapor diffusion method by mixing $200 \mathrm{~nL}$ of protein with $100 \mathrm{~nL}$ of precipitant solution $(0.1 \mathrm{M}$ Bicine, pH 8.5-9.0, 7.5-25\% PEG6000). Rod-shaped crystals appeared within $24 \mathrm{~h}$ and were cryoprotected using the precipitant solution containing 25\% PEG6000 and 20\% glycerol. Data were collected at ESRF Grenoble on beamlines ID30B, ID23-1, and ID30A-1 or at Diamond Light Source on beamline I04. Diffraction data were processed using the XDS package. ${ }^{38}$ All structures were solved using molecular replacement with PHASER $^{39}$ using the structure of TNKS2 (PDB code 5NOB) as a starting model. $\mathrm{Coot}^{40}$ and Refmac5 ${ }^{41}$ were used for model building and refinement, respectively. The images of the structures were prepared using PyMOL (The PyMOL Molecular Graphics System, version 1.8.4.0, Schrödinger, LLC.)

Western Blot Analysis. Western blot analysis of nuclear and cytoplasmic lysates from compound-treated COLO 320DM cells was performed as previously described ${ }^{26}$ using the following primary antibodies: tankyrase-1/2 (TNKS1/2, E-10, sc-365897, Santa Cruz Biotechnology), AXIN1 (C7B12, 3323, Cell Signaling Technology), AXIN2 (76G6, 2151, Cell Signaling Technology), non-phospho (active) $\beta$-catenin (D13A1, 8814, Cell Signaling Technology), $\beta$ catenin (610153,1:500, BD Biosciences). Actin (A2066, SigmaAldrich) and lamin B1 (ab16048, Abcam) were used as loading controls. Primary antibodies were visualized with HRP-conjugated secondary antibodies (mouse anti-rabbit IgG, sc-2357, Santa Cruz Biotechnology or donkey anti-rabbit IgG, 711-035-152, Jackson ImmunoResearch) using ChemiDoc Touch Imaging System (BioRad).

RNA Isolation and Real-Time qRT-PCR. RNA isolation and real-time qRT-PCR were performed as previously described ${ }^{26}$ using the following probes (all from Applied Biosystems): AXIN2 (Hs00610344_m1), DKK1 (Hs00183740 m1), NKD1 (Hs01548773_m1), APCDD1 (Hs00537787_m1), and GAPDH (Hs02758991_g1).

Proliferation Assay. 1000 COLO 320DM cells per well were seeded in 96-well plates. The day after, cell culture medium was changed to contain various doses of $\mathbf{1 3}(n=4)$ or vehicle (DMSO, Sigma-Aldrich) and the plates were incubated at $37^{\circ} \mathrm{C}$ for 5 days. The cells were incubated for $1 \mathrm{~h}$ at $37^{\circ} \mathrm{C}$ with CellTiter 96 AQueous nonradioactive cell proliferation assay (MTS, Promega) according to the supplier's recommendations. Abs $_{490}$ was measured (Wallac 1420 Victor2 microplate reader, PerkinElmer) and compared to $\mathrm{Abs}_{490}\left(t_{0}\right)$ using the following formula to determine single well values relative to the DMSO vehicle control: (sample $A_{490}-$ average $\left.A_{490} t_{0}\right) \times 100 /$ (average $A_{490}$ [for $0.01 \%$ DMSO controls] - average $A_{490} t_{0}$ ).

\section{ASSOCIATED CONTENT}

\section{(s) Supporting Information}

The Supporting Information is available free of charge at https://pubs.acs.org/doi/10.1021/acs.jmedchem.0c00208.

General and specific synthetic procedures and spectra (PDF)
Additional figures and tables for inhibition data and crystallography (PDF)

Molecular formula strings and some data (CSV)

\section{Accession Codes}

Atomic coordinates and structure factors have been deposited to Protein Data Bank with accession codes 6TG4, 6TKM, $6 \mathrm{TKN}, 6 \mathrm{TKP}, 6 \mathrm{TKQ}, 6 \mathrm{TKR}$, and 6TKS.

\section{AUTHOR INFORMATION}

\section{Corresponding Author}

Jo Waaler - Hybrid Technology Hub-Centre of Excellence, Institute of Basic Medical Sciences, University of Oslo, 0317 Oslo, Norway; Department of Immunology and Transfusion Medicine, Oslo University Hospital, 0424 Oslo, Norway; 두 orcid.org/0000-0002-8501-6225; Phone: +47 230790 14; Email: jo.waaler@rr-research.no

\section{Authors}

Ruben G. G. Leenders - Mercachem BV, 6546 BB Nijmegen, The Netherlands

Sven T. Sowa - Faculty of Biochemistry and Molecular Medicine, Biocenter Oulu, University of Oulu, 90014 Oulu, Finland

Shoshy Alam Brinch - Hybrid Technology Hub-Centre of Excellence, Institute of Basic Medical Sciences, University of Oslo, 0317 Oslo, Norway; Department of Immunology and Transfusion Medicine, Oslo University Hospital, 0424 Oslo, Norway

Max Lycke - Hybrid Technology Hub-Centre of Excellence, Institute of Basic Medical Sciences, University of Oslo, 0317 Oslo, Norway; Department of Immunology and Transfusion Medicine, Oslo University Hospital, 0424 Oslo, Norway

Piotr Nieczypor - Mercachem BV, 6546 BB Nijmegen, The Netherlands

Sjoerd Aertssen - Mercachem BV, 6546 BB Nijmegen, The Netherlands

Sudarshan Murthy - Faculty of Biochemistry and Molecular Medicine, Biocenter Oulu, University of Oulu, 90014 Oulu, Finland

Albert Galera-Prat - Faculty of Biochemistry and Molecular Medicine, Biocenter Oulu, University of Oulu, 90014 Oulu, Finland

Eddy Damen - Mercachem BV, 6546 BB Nijmegen, The Netherlands

Anita Wegert - Mercachem BV, 6546 BB Nijmegen, The Netherlands

Marc Nazaré - Medicinal Chemistry, Leibniz-Forschungsinstitut für Molekulare Pharmakologie (FMP), Campus Berlin Buch, 13125 Berlin, Germany

Lari Lehtiö - Faculty of Biochemistry and Molecular Medicine, Biocenter Oulu, University of Oulu, 90014 Oulu, Finland; (1) orcid.org/0000-0001-7250-832X

Stefan Krauss - Hybrid Technology Hub-Centre of Excellence, Institute of Basic Medical Sciences, University of Oslo, 0317 Oslo, Norway; Department of Immunology and Transfusion Medicine, Oslo University Hospital, 0424 Oslo, Norway

Complete contact information is available at: https://pubs.acs.org/10.1021/acs.jmedchem.0c00208

\section{Author Contributions}

\#J.W., R.G.G.L., and S.T.S. contributed equally. The manuscript was written through contributions of all authors, and all 
authors have given approval to the final version of the manuscript.

\section{Funding}

J.W. and S.K. were supported by the Research Council of Norway (Grants 262613, 267639, and 296226), by SouthEastern Norway Regional Health Authority (Grants 16/005289, 15/00779-2, 2015012, and 2019090), and by the Norwegian Cancer Society (Grant 5803958). L.L., S.T.S., A.G.-P., and S.M. were supported by the Jane and Aatos Erkko Foundation, Sigrid Jusélius Foundation, and Academy of Finland (Grants 287063, 294085, and 319299).

\section{Notes}

The authors declare the following competing financial interest(s): J.W., M.N., L.L., A.W., R.G.G.L., and S.K. hold patents related to tankyrase inhibitor therapy, and these authors declare no additional interests. The remaining authors declare no competing interests.

\section{ACKNOWLEDGMENTS}

Heli Alanen and Dr. Yves Nkizinkiko are acknowledged for their contributions in performing some of the biochemical assays. Ilonka Meerts and Eef van den Elzen, both of Mercachem BV, are acknowledged for their contributions with the human and mouse microsomal stability assay. Protein crystallography experiments were performed at the Diamond Light Source (Didcot, U.K.) on beamline I04, and at European Synchrotron Radiation Facility (ESRF, Grenoble, France) on beamlines ID30B, ID23-1, and ID30A-1. We are grateful to local contacts for providing assistance in using the beamlines. The use of the facilities and expertise of the Biocenter Oulu Protein Crystallography Core Facility, a member of Biocenter Finland and Instruct-FI, is gratefully acknowledged.

\section{ABBREVIATIONS USED}

ADME, absorption, distribution, metabolism, and excretion; $\mathrm{ADP}$, adenosine $5^{\prime}$-diphosphate; AKT, serine/threonine kinase; AMOT, angiomotin; AMP, adenosine monophosphate; AMPK, AMP-activated protein kinase; APC, adenomatous polyposis coli; APCDD1, APC down-regulated 1; ARTD, diphtheria toxin-like ADP-ribosyltransferase; AT, atropisomer; AUC, area under the curve; AXIN, axis inhibition protein; Boc, tert-butyloxycarbonyl; CDI, N,N'-carbonyldiimidazole; $\mathrm{Cl}$, clearance; DIPEA, diisopropylethylamine; DKK1, dickkopf WNT signaling pathway inhibitor 1; DMA, N,N-dimethylacetamide; DMF, N,N-dimethylformamide; DMSO, dimethyl sulfoxide; EGFR, epidermal growth factor receptor; equiv, equivalents; GSK $3 \beta$, glycogen synthase kinase $3 \beta$; HATU, hexafluorophosphate azabenzotriazole tetramethyluronium; HEK293, human embryonic kidney 293; hERG, human ether-à-go-go-related gene; HPLC, high pressure liquid chromatography; LATS1/2, large tumor suppressor kinase 1 and 2; LC/MS, liquid chromatography/mass spectroscopy; MPLC, medium pressure liquid chromatography; MRT, mean residence time; MTS, 3-(4,5-dimethylthiazol-2-yl)-5-(3-carboxymethoxyphenyl)-2-(4-sulfophenyl)-2H-tetrazolium; NKD1, NKD inhibitor of WNT signaling pathway 1; NAD, nicotinamide adenine dinucleotide; NMR, nuclear magnetic resonance; PARP, poly-ADP-ribose polymerase; PARsylate, poly(ADP-ribose)sylate; PDA, photodiode array; PI3K, phosphoinositide-3-kinase; PK, pharmacokinetics; po, per oral; PPB, plasma protein binding; RT-qPCR, reverse transcription quantitative polymerase chain reaction;
RNF146, ring finger protein 146; SD, standard deviation; SFC, supercritical fluid chromatography; $t_{1 / 2}$, half-life; TAZ, tafazzin; TEAD, TEA domain transcription factor; TFA, trifluoroacetic acid; TLC, thin layer chromatography; TNKS, telomeric repeat factor (TRF1)-interacting ankyrin-related ADP-ribose polymerases, tankyrase; TNKS1/2, tankyrase 1 and tankyrase 2; tPSA, total polar surface area; $\mathrm{Vd}$, volume of distribution; WNT, wingless-type mammary tumor virus integration site; YAP, yes associated protein 1

\section{REFERENCES}

(1) Haikarainen, T.; Krauss, S.; Lehtio, L. Tankyrases: structure, function and therapeutic implications in cancer. Curr. Pharm. Des. 2014, 20, 6472-6488.

(2) Huang, S. M.; Mishina, Y. M.; Liu, S.; Cheung, A.; Stegmeier, F.; Michaud, G. A.; Charlat, O.; Wiellette, E.; Zhang, Y.; Wiessner, S.; Hild, M.; Shi, X.; Wilson, C. J.; Mickanin, C.; Myer, V.; Fazal, A.; Tomlinson, R.; Serluca, F.; Shao, W.; Cheng, H.; Shultz, M.; Rau, C.; Schirle, M.; Schlegl, J.; Ghidelli, S.; Fawell, S.; Lu, C.; Curtis, D.; Kirschner, M. W.; Lengauer, C.; Finan, P. M.; Tallarico, J. A.; Bouwmeester, T.; Porter, J. A.; Bauer, A.; Cong, F. Tankyrase inhibition stabilizes axin and antagonizes Wnt signalling. Nature 2009, $461,614-620$.

(3) Wang, W.; Li, N.; Li, X.; Tran, M. K.; Han, X.; Chen, J. Tankyrase inhibitors target YAP by stabilizing angiomotin family proteins. Cell Rep. 2015, 13, 524-532.

(4) Bhardwaj, A.; Yang, Y.; Ueberheide, B.; Smith, S. Whole proteome analysis of human tankyrase knockout cells reveals targets of tankyrase-mediated degradation. Nat. Commun. 2017, 8, 2214.

(5) Kim, M. K. Novel insight into the function of tankyrase. Oncol. Lett. 2018, 16, 6895-6902.

(6) Li, N.; Wang, Y.; Neri, S.; Zhen, Y.; Fong, L. W. R.; Qiao, Y.; Li, X.; Chen, Z.; Stephan, C.; Deng, W.; Ye, R.; Jiang, W.; Zhang, S.; Yu, Y.; Hung, M. C.; Chen, J.; Lin, S. H. Tankyrase disrupts metabolic homeostasis and promotes tumorigenesis by inhibiting LKB1-AMPK signalling. Nat. Commun. 2019, 10, 4363.

(7) Chen, B.; Dodge, M. E.; Tang, W.; Lu, J.; Ma, Z.; Fan, C. W.; Wei, S.; Hao, W.; Kilgore, J.; Williams, N. S.; Roth, M. G.; Amatruda, J. F.; Chen, C.; Lum, L. Small molecule-mediated disruption of Wntdependent signaling in tissue regeneration and cancer. Nat. Chem. Biol. 2009, 5, 100-107.

(8) Waaler, J.; Machon, O.; Tumova, L.; Dinh, H.; Korinek, V.; Wilson, S. R.; Paulsen, J. E.; Pedersen, N. M.; Eide, T. J.; Machonova, O.; Gradl, D.; Voronkov, A.; von Kries, J. P.; Krauss, S. A novel tankyrase inhibitor decreases canonical Wnt signaling in colon carcinoma cells and reduces tumor growth in conditional APC mutant mice. Cancer Res. 2012, 72, 2822-2832.

(9) Voronkov, A.; Holsworth, D. D.; Waaler, J.; Wilson, S. R.; Ekblad, B.; Perdreau-Dahl, H.; Dinh, H.; Drewes, G.; Hopf, C.; Morth, J. P.; Krauss, S. Structural basis and SAR for G007-LK, a lead stage 1,2,4-triazole based specific tankyrase $1 / 2$ inhibitor. J. Med. Chem. 2013, 56, 3012-3023.

(10) Bregman, H.; Chakka, N.; Guzman-Perez, A.; Gunaydin, H.; Gu, Y.; Huang, X.; Berry, V.; Liu, J.; Teffera, Y.; Huang, L.; Egge, B.; Mullady, E. L.; Schneider, S.; Andrews, P. S.; Mishra, A.; Newcomb, J.; Serafino, R.; Strathdee, C. A.; Turci, S. M.; Wilson, C.; Dimauro, E. F. Discovery of novel, induced-pocket binding oxazolidinones as potent, selective, and orally bioavailable tankyrase inhibitors. J. Med. Chem. 2013, 56, 4320-4342.

(11) Anumala, U. R.; Waaler, J.; Nkizinkiko, Y.; Ignatev, A.; Lazarow, K.; Lindemann, P.; Olsen, P. A.; Murthy, S.; Obaji, E.; Majouga, A. G.; Leonov, S.; von Kries, J. P.; Lehtio, L.; Krauss, S.; Nazare, M. Discovery of a novel series of tankyrase inhibitors by a hybridization approach. J. Med. Chem. 2017, 60, 10013-10025.

(12) Bregman, H.; Chakka, N.; Guzman-Perez, A.; Gunaydin, H.; Gu, Y.; Huang, X.; Berry, V.; Liu, J.; Teffera, Y.; Huang, L.; Egge, B.; Mullady, E. L.; Schneider, S.; Andrews, P. S.; Mishra, A.; Newcomb, J.; Serafino, R.; Strathdee, C. A.; Turci, S. M.; Wilson, C.; DiMauro, E. 
F. Discovery of novel, induced-pocket binding oxazolidinones as potent, selective, and orally bioavailable tankyrase inhibitors. J. Med. Chem. 2013, 56, 4320-4342.

(13) Haikarainen, T.; Waaler, J.; Ignatev, A.; Nkizinkiko, Y.; Venkannagari, H.; Obaji, E.; Krauss, S.; Lehtio, L. Development and structural analysis of adenosine site binding tankyrase inhibitors. Bioorg. Med. Chem. Lett. 2016, 26, 328-333.

(14) Nkizinkiko, Y.; Suneel Kumar, B. V.; Jeankumar, V. U.; Haikarainen, T.; Koivunen, J.; Madhuri, C.; Yogeeswari, P.; Venkannagari, H.; Obaji, E.; Pihlajaniemi, T.; Sriram, D.; Lehtio, L. Discovery of potent and selective nonplanar tankyrase inhibiting nicotinamide mimics. Bioorg. Med. Chem. 2015, 23, 4139-4149.

(15) McGonigle, S.; Chen, Z.; Wu, J.; Chang, P.; Kolber-Simonds, D.; Ackermann, K.; Twine, N. C.; Shie, J. L.; Miu, J. T.; Huang, K. C.; Moniz, G. A.; Nomoto, K. E7449: A dual inhibitor of PARP1/2 and tankyrase $1 / 2$ inhibits growth of DNA repair deficient tumors and antagonizes Wnt signaling. Oncotarget 2015, 6, 41307-41323.

(16) Paine, H. A.; Nathubhai, A.; Woon, E. C.; Sunderland, P. T.; Wood, P. J.; Mahon, M. F.; Lloyd, M. D.; Thompson, A. S.; Haikarainen, T.; Narwal, M.; Lehtio, L.; Threadgill, M. D. Exploration of the nicotinamide-binding site of the tankyrases, identifying 3arylisoquinolin-1-ones as potent and selective inhibitors in vitro. Bioorg. Med. Chem. 2015, 23, 5891-5908.

(17) Ferri, M.; Liscio, P.; Carotti, A.; Asciutti, S.; Sardella, R.; Macchiarulo, A.; Camaioni, E. Targeting Wnt-driven cancers: Discovery of novel tankyrase inhibitors. Eur. J. Med. Chem. 2017, $142,506-522$.

(18) Mizutani, A.; Yashiroda, Y.; Muramatsu, Y.; Yoshida, H.; Chikada, T.; Tsumura, T.; Okue, M.; Shirai, F.; Fukami, T.; Yoshida, M.; Seimiya, H. RK-287107, a potent and specific tankyrase inhibitor, blocks colorectal cancer cell growth in a preclinical model. Cancer Sci. 2018, 109, 4003-4014.

(19) Buchstaller, H. P.; Anlauf, U.; Dorsch, D.; Kuhn, D.; Lehmann, M.; Leuthner, B.; Musil, D.; Radtki, D.; Ritzert, C.; Rohdich, F.; Schneider, R.; Esdar, C. Discovery and optimization of 2arylquinazolin-4-ones into a potent and selective tankyrase inhibitor modulating Wnt pathway activity. J. Med. Chem. 2019, 62, 78977909.

(20) Nathubhai, A.; Haikarainen, T.; Koivunen, J.; Murthy, S.; Koumanov, F.; Lloyd, M. D.; Holman, G. D.; Pihlajaniemi, T.; Tosh, D.; Lehtio, L.; Threadgill, M. D. Highly potent and isoform selective dual site binding tankyrase/Wnt signaling inhibitors that increase cellular glucose uptake and have antiproliferative activity. J. Med. Chem. 2017, 60, 814-820.

(21) Sanchez-Vega, F.; Mina, M.; Armenia, J.; Chatila, W. K.; Luna, A.; La, K. C.; Dimitriadoy, S.; Liu, D. L.; Kantheti, H. S.; Saghafinia, S.; Chakravarty, D.; Daian, F.; Gao, Q.; Bailey, M. H.; Liang, W. W.; Foltz, S. M.; Shmulevich, I.; Ding, L.; Heins, Z.; Ochoa, A.; Gross, B.; Gao, J.; Zhang, H.; Kundra, R.; Kandoth, C.; Bahceci, I.; Dervishi, L.; Dogrusoz, U.; Zhou, W.; Shen, H.; Laird, P. W.; Way, G. P.; Greene, C. S.; Liang, H.; Xiao, Y.; Wang, C.; Iavarone, A.; Berger, A. H.; Bivona, T. G.; Lazar, A. J.; Hammer, G. D.; Giordano, T.; Kwong, L. N.; McArthur, G.; Huang, C.; Tward, A. D.; Frederick, M. J.; McCormick, F.; Meyerson, M.; Van Allen, E. M.; Cherniack, A. D.; Ciriello, G.; Sander, C.; Schultz, N. Oncogenic signaling pathways in the cancer genome atlas. Cell 2018, 173, 321-337.

(22) Nusse, R.; Clevers, H. Wnt/beta-catenin signaling, disease, and emerging therapeutic modalities. Cell 2017, 169, 985-999.

(23) Krishnamurthy, N.; Kurzrock, R. Targeting the Wnt/betacatenin pathway in cancer: Update on effectors and inhibitors. Cancer Treat. Rev. 2018, 62, 50-60.

(24) Lau, T.; Chan, E.; Callow, M.; Waaler, J.; Boggs, J.; Blake, R. A.; Magnuson, S.; Sambrone, A.; Schutten, M.; Firestein, R.; Machon, O.; Korinek, V.; Choo, E.; Diaz, D.; Merchant, M.; Polakis, P.; Holsworth, D. D.; Krauss, S.; Costa, M. A Novel Tankyrase small-molecule inhibitor suppresses APC mutation-driven colorectal tumor growth. Cancer Res. 2013, 73, 3132-3144.

(25) Martins-Neves, S. R.; Paiva-Oliveira, D. I.; Fontes-Ribeiro, C.; Bovee, J.; Cleton-Jansen, A. M.; Gomes, C. M. F. IWR-1, a tankyrase inhibitor, attenuates Wnt/beta-catenin signaling in cancer stem-like cells and inhibits in vivo the growth of a subcutaneous human osteosarcoma xenograft. Cancer Lett. 2018, 414, 1-15.

(26) Solberg, N. T.; Waaler, J.; Lund, K.; Mygland, L.; Olsen, P. A.; Krauss, S. Tankyrase inhibition enhances the antiproliferative effect of PI3K and EGFR inhibition, mutually affecting beta-catenin and AKT signaling in colorectal cancer. Mol. Cancer Res. 2018, 16, 543-553.

(27) Waaler, J.; Mygland, L.; Tveita, A.; Strand, M. F.; Solberg, N. T.; Olsen, P. A.; Aizenshtadt, A.; Fauskanger, M.; Lund, K.; Brinch, S. A.; Lycke, M.; Dybing, E.; Nygaard, V.; Boe, S. L.; Heintz, K. M.; Hovig, E.; Hammarstrom, C.; Corthay, A.; Krauss, S. Tankyrase inhibition sensitizes melanoma to PD-1 immune checkpoint blockade in syngeneic mouse models. Commun. Biol. 2020, 3, 196.

(28) Fujita, S.; Mukai, T.; Mito, T.; Kodama, S.; Nagasu, A.; Kittaka, M.; Sone, T.; Ueki, Y.; Morita, Y. Pharmacological inhibition of tankyrase induces bone loss in mice by increasing osteoclastogenesis. Bone 2018, 106, 156-166.

(29) Norum, J. H.; Skarpen, E.; Brech, A.; Kuiper, R.; Waaler, J.; Krauss, S.; Sorlie, T. The tankyrase inhibitor G007-LK inhibits small intestine LGR5(+) stem cell proliferation without altering tissue morphology. Biol. Res. 2018, 51, 3.

(30) Waaler, J.; Machon, O.; von Kries, J. P.; Wilson, S. R.; Lundenes, E.; Wedlich, D.; Gradl, D.; Paulsen, J. E.; Machonova, O.; Dembinski, J. L.; Dinh, H.; Krauss, S. Novel synthetic antagonists of canonical Wnt signaling inhibit colorectal cancer cell growth. Cancer Res. 2011, 71, 197-205.

(31) Krauss, S.; Nazare, M.; Anumala, U.; Lethio, L.; Waaler, J.; Holsworth, D.; Wegert, A.; Leenders, R. Triazole derivates as tankyrase inhibitors. WO/2018/118868, 2018.

(32) Sugane, T.; Tobe, T.; Hamaguchi, W.; Shimada, I.; Maeno, K.; Miyata, J.; Suzuki, T.; Kimizuka, T.; Sakamoto, S.; Tsukamoto, S. Atropisomeric 4-phenyl-4H-1,2,4-triazoles as selective glycine transporter 1 inhibitors. J. Med. Chem. 2013, 56, 5744-5756.

(33) Laplante, S. R.; Fader, L. D.; Fandrick, K. R.; Fandrick, D. R.; Hucke, O.; Kemper, R.; Miller, S. P.; Edwards, P. J. Assessing atropisomer axial chirality in drug discovery and development. J. Med. Chem. 2011, 54, 7005-7022.

(34) Narwal, M.; Fallarero, A.; Vuorela, P.; Lehtio, L. Homogeneous screening assay for human tankyrase. J. Biomol. Screening 2012, 17, $593-604$.

(35) Venkannagari, H.; Fallarero, A.; Feijs, K. L.; Luscher, B.; Lehtio, L. Activity-based assay for human mono-ADP-ribosyltransferases ARTD7/PARP15 and ARTD10/PARP10 aimed at screening and profiling inhibitors. Eur. J. Pharm. Sci. 2013, 49, 148-156.

(36) Venkannagari, H.; Verheugd, P.; Koivunen, J.; Haikarainen, T.; Obaji, E.; Ashok, Y.; Narwal, M.; Pihlajaniemi, T.; Luscher, B.; Lehtio, L. Small-molecule chemical probe rescues cells from mono-ADPRibosyltransferase ARTD10/PARP10-induced apoptosis and sensitizes cancer cells to DNA damage. Cell Chem. Biol. 2016, 23, 12511260.

(37) Murthy, S.; Desantis, J.; Verheugd, P.; Maksimainen, M. M.; Venkannagari, H.; Massari, S.; Ashok, Y.; Obaji, E.; Nkizinkinko, Y.; Luscher, B.; Tabarrini, O.; Lehtio, L. 4-(Phenoxy) and 4-(benzyloxy)benzamides as potent and selective inhibitors of mono-ADPribosyltransferase PARP10/ARTD10. Eur. J. Med. Chem. 2018, 156, 93-102.

(38) Kabsch, W. Xds. Acta Crystallogr., Sect. D: Biol. Crystallogr. 2010, 66, 125-132.

(39) McCoy, A. J.; Grosse-Kunstleve, R. W.; Adams, P. D.; Winn, M. D.; Storoni, L. C.; Read, R. J. Phaser crystallographic software. J. Appl. Crystallogr. 2007, 40, 658-674.

(40) Emsley, P.; Cowtan, K. Coot: model-building tools for molecular graphics. Acta Crystallogr., Sect. D: Biol. Crystallogr. 2004, 60, 2126-2132.

(41) Murshudov, G. N.; Skubak, P.; Lebedev, A. A.; Pannu, N. S.; Steiner, R. A.; Nicholls, R. A.; Winn, M. D.; Long, F.; Vagin, A. A. REFMAC5 for the refinement of macromolecular crystal structures. Acta Crystallogr., Sect. D: Biol. Crystallogr. 2011, 67, 355-367. 